\title{
Early Islamic Cosmopolitanism? Constructing the 'Umma of India in Pre-Mongol Muslim Scholarship
}

\author{
Edmund Hayes \\ Leiden University \\ e.p.hayes@hum.leidenuniv.nl
}

This article analyzes possible avenues for the study of a pre-Mongol Islamic cosmopolitanism. The ways in which the archetypically idolatrous land of India is treated by Islamicate thinkers of the 'Abbasid empire and after illuminates an Islamic cosmopolitanism that managed to incorporate the other into its view of human history and religious history. Two major fields for the generation of cosmopolitan ideas are analyzed: narratives drawn from historiography, and taxonomies erected by theological-heresiographical works. Both frameworks rely on a Muslim model of history and society in which divine truth and guidance are mediated to the communities ('umma, 'umam) of the world firstly by a prophet, but also by sages and philosopher-kings: figures who play important roles in Muslim accounts of India. Through applying these "universal" categories to Indian subject-matter, Muslim thinkers were able to depict Indians as partners in the human struggle to attain and preserve truth, albeit falling short of the Muslim community in various ways. In both the historiographical and the heresiographical fields, cosmopolitan and anti-cosmopolitan trends are observable. By incorporating Indian narratives into a universalizing historical vision, Mas'ūdī can best be seen to approach a cosmopolitan sensibility among thinkers within historiographic discourse. Bīrūnī goes furthest among the thinkers working within a theological-heresiographical framework in analogizing Indian philosophy with Muslim thought. It is argued that both thinkers achieve a kind of cosmopolitanism only through an elitist denigration of the commoners of their communities. In addition, their cosmopolitanism was predicated on imperial expansionism into India.

Keywords: community, India, idolatry, empire studies, historiography, theology, 'Abbasid, cosmopolitanism, conquest, cultural studies

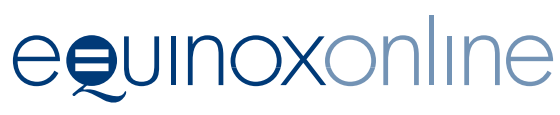




\section{Introduction}

Recent research has highlighted the cosmopolitan nature of the later medieval and early modern Persianate and Islamicate worlds, invoking such vocabulary as the "Medieval Islamic Republic of Letters," (al-Musawi 2015) or the "post-Mongol Persianate Cosmopolis," (Eaton and Wagoner 2014; Melvin-Koushki 2016) ${ }^{1}$ the latter based partly on theoretical developments in scholarship on other cultural zones such as Sheldon Pollock's "Sanskrit Cosmopolis" (Eaton and Wagoner 2014, 20-27). In studies of the pre-Mongol period, there has been less invocation of cosmopolitanism, but the cosmopolitan aspect of pre-Mongol Muslim societies also merits attention. If there is a mention of cosmopolitanism in this era, it tends to focus on the sociological fact of the diversity of imperial society (Lapidus 2002,92 ) often implicitly or explicitly contrasting a cosmopolitan 'Abbasid imperial style with the supposedly less cosmopolitan Umayyads. ${ }^{2}$ Fewer are the contributions which investigate the theoretical articulations of a pre-Mongol Persian or Islamic cosmopolitanism. It is generally accepted in the study of empire that empires are intrinsically cosmopolitan and cosmopolitanizing spaces, placing a metropolitan elite in power over a heterogenous set of societies which, in their turn, influence the nature and composition of the imperial elite. However this aspect of early Islamic imperial culture has been sparsely discussed. Having said that, this article will not take the cosmopolitan aspects of pre-Mongol Islamic imperial society as its primary focus, but instead will focus on some of the ways in which we can meaningfully talk about pre-Mongol cosmopolitan thought.

While I acknowledge the importance of understanding in more detail the cosmopolitan elements of the 'Abbasid imperial project and its aftermath, and, in particular the intersection of the theory and practice of government, legislation and Islamic law, this article will focus instead on two major fields for the discussion of cosmopolitanism: the narrative-historical and the theological-doctrinal. In both we can identify a tension between cosmopolitan and anti-cosmopolitan tendencies. In the narrative-historical field, the resolution of this tension will result either in

1. See also Shahab Ahmed (2016) and his conception of a Medieval-Early Modern "Balkans to Bengal complex" characterized by diversity and contradiction. All of these theorizations owe some debt to Marshall Hodgson's original contribution of the terms "Islamicate" and "Persianate," though in many cases emerging from a critique of Hodgson's usage, rather than an endorsement of it.

2. Regarding the importance of recognizing the diversity of Umayyad society, see below.

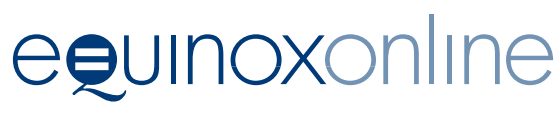


the denial or the assertion of common origins and fates between different historical communities ('umma, 'umam). In the theological-doctrinal field, it will result in the denial or assertion of doctrinal commonalities between religious communities. We should not expect the assertion of commonalities between non-Muslim and Muslim to result in the displacement of the centrality of the Muslim community as the most perfectly touched by divine guidance. However, a cosmopolitan orientation will undermine the sense of the Muslim community being historically and theologically unique in its interactions with the divine, instead projecting a kinship between communities. In order to resolve these tensions in a cosmopolitan direction, it was necessary to embark on a process of domestication and assimilation of foreign material to Muslim categories which reworked, even deracinated the original material, but also resulted in spaces within Muslim discourse which allowed for substantive engagement with non-Muslim thinking. In both the historical field and the theological field, we see the emergence of new kinds of literature to deal with this process. In the historical field, we see the rise of the so-called "universal histories," and in the theological field, we see the emergence, first of pan-Muslim heresiographies which sought to assimilate all doctrinal variants within the community to a common set of analytic standards, and thereafter of works of comparative religion which went further, assimilating also non-Muslim religions to a set of categories previously developed for the understanding of Islamic sects.

In order to engage with the concept of cosmopolitanism as it might relate to knowledge production in the pre-Mongol Muslim empires, we must be aware of both the genealogy of the term as it is used today, and the relevant social and intellectual formations which might have furnished fertile soil for the development of cosmopolitanism in the context under discussion. In the context of a journal issue dedicated to "Iranian Cosmopolitanisms," we must concede that both terms in this phrase are largely alien to the pre-Mongol period. While the term "cosmopolitan" has no direct analogy in any of the texts here analyzed, we can detect relevant social and intellectual developments that arise from the 'Abbasid imperial project in the eighth-tenth centuries $\mathrm{CE}$, which may meaningfully be discussed under the rubric of cosmopolitanism. As for the terms "Iran" or "Iranian", these tended to be relegated to the context of the distant past, rather than describing identity in the realm of lived experience (Bowen Savant 2013) and even so, in the texts analyzed, the word Persian ( $f \bar{a} r s, f \bar{a} r i s \bar{\imath})$ is dominant. The relevance of this article to something that

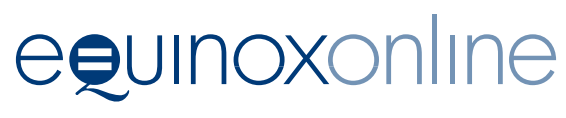


is "Iranian" in the sense of the modern nation state of Iran, is, therefore, tangential, though it is incontrovertible that the historiographical visions analyzed below are significant for thinkers who attempt to understand discuss and theorize "Iran" in the era of nation states (Tavakoli-Taraghi 1996). While I will be discussing writers who operated in and around the boundaries of the Middle East, Persia and modern day Iran, the major focus of my attention will be the 'Abbasid political-cultural domain, and its successors following the fragmentation of 'Abbasid control in the ninth and tenth centuries CE. Therefore, I will not attempt to theorize an exclusively "Iranian" or "Persian" cosmopolitanism, but will focus on terms of reference set by the hegemonic framework for thought in this cultural zone at this moment in history: Islam, which related the formation of historical and cultural communities to the all-important history of prophecy and monotheism. The communities represented in these discourses are referred to in Arabic, Persian and cognate languages as "umma" or "milla" and are understood to encompass both a historical-cultural dimension and a religious dimension.

I will use discourses on India as a test case for exposing a set of debates that have implications for cosmopolitan thinking in this period. I focus on India due to its position in Muslim discourse as archetypically idolatrous, and therefore opposed to one of the central messages of Islam, with its Qur'ānic polemic against Arabian idolatry. Given that Indian prophets and sages were absent from the Qur'ān, India resisted easy incorporation into Qur'ānic-biblical prophetic history around which Muslim historical identity was constructed. While I will use the English word "India" broadly to connote the terms covered by the Arabic words Hind and Sind, it should also be understood that Hind is sometimes understood to include Sind, and sometimes to extend far beyond what is now understood as the Indian subcontinent to also include South-East Asia by extension (Wink 2003, 1: 192). ${ }^{3}$ The specific dimensions and boundaries of these lands are not particularly important to the present argument, as I will primarily be discussing not the reality of a particular culture or region, but rather the construction of India in the Muslim imaginary, crystallized into literary

3. As Wink puts it, the "Arabic term Hind covers both South Asia and Indianized Southeast Asia. And the term is a political one rather than geographical in its literal sense. Al-Hind is conceived of as a 'realm' ('ard) which belongs to a great number of kings who are Hindu or Buddhist, 'the kings of al-Hind,' whose territories have no hardand-fast boundaries but interpenetrate each other and are 'open' to the world beyond." See also S. Maqbul Ahmad "Hind. i.- The Geography of India according to the mediaeval Muslim geographers," EI2.

\section{eevunoxonlıne}


narrative. That being said, it is important to recognize that the process of the construction of this image of India had real-world consequences in structuring the kinds of interactions that Muslims had when travelling East into India.

Ideas about India in the early Muslim empire and its successors were heavily influenced by the traditions of thinking about India inherited from its late Antique predecessors. While terms like Hind and Sind were vehicles for the reconstitution of new identities based upon the new relationship between the Muslim rulers and their subjects, the meanings they organized were not created ex nihilo, but rather were reworkings of things known already by people in Iraq, Khurasan, and Central Asia as well as absorbed directly from the diverse lands of India themselves. The same can be said of numerous new identities and relationships which came out of the experience of the Muslim synthesis, and the new relationships created by Muslim rule: Muslim-Christian and Muslim-Jewish relations; Arab-Berber, Arab-Copt, Arab-Ajam or Arab-Persian, and so on (Webb 2016). None of these new relationships was based on the intersection of stable essences, but rather came about through the process of interrelation and juxtaposition of dynamic entities. For obvious reasons of geographical contiguity, Islamic perceptions of India tended to be filtered through the Persian cultural zone. But it should not be thought that this zone was itself mono-cultural or monoglot. In addition to the centuries-old contact between Sasanian Persia and the Indian subcontinent which left rich traces in the literary record through translations and encounters, Islamic understandings of Sind and Hind were mediated in a large part by 'Persians' who had even stronger cultural ties to Indian religion such as the originally Buddhist Barmakids from Balkh in the region of Tukhāristān whose native tongue had been Bactrian (van Bladel 2011).

The Central Asian polymath Abū Rayhān al-Bīrūnī (d. after 442/1050) is rightly regarded as unique in his intellectual engagement with India, but, I would argue that this engagement was precedented in important ways by the cosmopolitan worldview present in the 'Abbasid universal histories of the previous century. I will show how we can discern cosmopolitan thinking also in the histories of Abū al-'Abbās Aḥmad al-Ya'qūbī (d. after 292/905) and Abū al-Hasan 'Alī al-Mas'ūdī (d. 345/ 956). While the cosmopolitan thinking of these three has limitations, we can discern in each a process by which the alterity of India is tempered by a certain historiographical and theological domestication of the other. Through historical

4. For this dating, see Muhammad Qasim Zaman, "Al-Ya ḳūb̄̄", EI2.

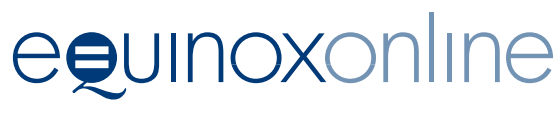


parallels, they construct India, not as an essentially alien zone, but rather a participant in the history of the human struggle towards truth, albeit within a sacred history that gives Islam and the message of Muhammad a pivotal place.

\section{Thinking about cosmopolitanism}

In Lucian Stone's volume on "Iranian identity and cosmopolitanism" that this special issue responds to, Lueck offers an overview of some of the major understandings of cosmopolitanism. He distinguishes articulations of the sheer fact of social diversity from cosmopolitanism as a kind of political theory or as a morally normative prescription. In broadly identifying what constitutes cosmopolitanism as an intellectual position, Lueck states:

"We can begin to clarify the sense of the term by identifying a single, very broad commitment that all forms of cosmopolitan thought share, namely, that all human beings belong, or ought to be treated as if they belong, to one worldwide community." (Lueck 2014, 159)

In looking for examples of cosmopolitan thinking, then, we must be alive to ideologies of community, which will inevitably involve the construction of the other: either as sharing common goals and features, or as irredeemably separated by its alterity.

While I will primarily be focusing on types of cosmopolitanism thinking, rather than the mere fact of diversity in society, it must also be admitted that there is a connection between the two. Starting with the broadest level of commitment to cosmopolitan thinking that Lueck identifies, it should be understood that all systems of thought could be assigned a value within a spectrum between pro-cosmopolitanism and anti-cosmopolitan, while most discourses will include instances orientated towards each. In this sense, I will not attempt to identify thinking that fully embodies cosmopolitanism within a familiar European genealogy of the idea, but rather I will identify a set of debates about history and the taxonomical categorization of the communities of the world with which any pre-Mongol cosmopolitan thinking had to contend, and which continued to be influential thereafter. While, my primary aim will be to identify intellectual structures, rather than social structures, this will involve the recognition of the following overlapping factors:

- The cosmopolitan diversity of early Muslim society

- The existence of cosmopolitan intellectuals: people who travelled, read about and studied the wider world, and were therefore consciously

\section{eevunoxonline}


open to diverse influences which they incorporated in their work, giving rise to:

- The development of cosmopolitanism thinking among some of these intellectuals as an intellectual orientation that incorporated non-Muslim histories, cultures and religious traditions into a universalizing logic, which, although it promoted the primacy of the position of Islam and the Muslim community in the history of the world, suggested the existence of porous boundaries between communities, and allowed for the serious engagement with non-Muslim sources of knowledge.

\section{'Umma as polis}

In seeking cosmopolitan discourses, we must first define what might constitute a "polis" in the context of the pre-Mongol Muslim world. ${ }^{5}$ It is the word 'umma which best serves this function. Two broad senses in which the Qur'ān uses 'umma serve as a starting point: firstly, referring to the community of believers following Muhammad; and secondly, referring to communities who received prophecy from other prophets earlier in the history of the world. In the latter meaning, there is an overlap between the conception of 'umma as a voluntarily-formed community of belief and practice, and the idea of a community as a political and cultural nation or ethnie. As such, the conception of 'umma contains a certain contradiction between the idea of a grouping of (potentially culturally and ethnically diverse) individuals who choose to associate under the banner of a particular prophet's revelation, ${ }^{6}$ and the idea of 'umma as an inherited primordial politico-cultural community. ${ }^{7}$ Both conceptions continued to be influential in defining Muslim identities and relations with others. The idea of a voluntary association of the saved, opposed to those who reject Muhammad's message is central to the theological understanding of Muslim identity, including heresiographical accounts of the different

5. The nature of the polis determines the initial parameters of cosmopolitan thinking. Thus the foundational classical formulations of cosmopolitanism, originating in Stoic thought, started from a richly contextual understanding of what it meant to be a citizen of a Hellenic polis in an age of travel and intercultural cross-pollination (Pagden 2000, 4-6).

6. The so-called "umma document" or "constitution of Medina" documents the composite nature of the 'umma Muhammad formed, in which Muhammad's followers from Mecca and the Arab and Jewish tribes of Yathrib were bound to each other, while having their own "dīn." Fred Donner $(2010,68-74)$ terms this composite community "ecumenical."

7. Orwin (2017, 86-112) discusses this contradiction in the Qur'ān and later Muslim thinkers.

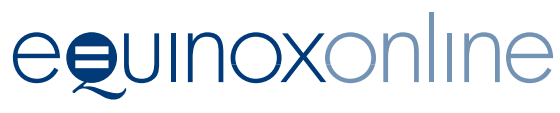


sects and other religions. On the other hand, the conception of an inherited community identity was influential in governance and therefrom flowed into the legal conception of community which was systematized through concepts such as the hierarchical separation of society into Muslims, People of the Book (ahl al-kitāb) and "idolaters" (mushrikūna), which had consequences for laws governing courts, social life and taxation, and the conduct of war and conquest (Waardenburg 1999).

\section{Responses to diversity in early Muslim society}

Cosmopolitan thinking is related to, but not determined by, the diversity of influences at play in a society. In its earliest phases, Islam, insofar as we can study it, ${ }^{8}$ appears to have been intrinsically founded upon synthesis, as diverse tribal, linguistic and ethnic groupings were forged together under its banner. There is a persistent stereotype (stemming from the old nationalistic narratives that pitted "Arab," against "Persian" without engaging with the constructed nature of these ethnonyms) that early Muslim and Umayyad society were characterized by monocultural Arab chauvinism, compared to the 'Abbasid caliphs with their capital near Ctesiphon and their Persian and Byzantine mothers. ${ }^{9}$ However, recent research on the period of the Islamic conquests is destabilizing older racialized dichotomies which separate the Arab chauvinism of the Umayyads from the cosmopolitan 'Abbāsids: ${ }^{10}$ Muslim society was diverse from its very beginning. While its meanings are contested, the "umma document" (so-called "Constitution of Medina") clearly lays out the vision that Muhammad's community was based on a synthesis of

8. The study of the earliest phases of Islam is intrinsically fraught with difficulty. In discussing these, Aaron Hughes (2017) argues that studying Islam with the modern category of "religion" obscures the fact that Islam and the religions it was in contact with in its earliest phase were not stable and bounded, but rather shared ideas and language fairly freely.

9. As a recent example of the dichotomization of the Umayyads and the 'Abbasids, Hamid Dabashi $(2012,14)$ writes, "humanism in fact began as a revolt against patently racialized tribalism of the Umayyad period (661-750), paving the way for the literary cosmopolitanism of the Abbasids."

10. See, for example, the case of exogamy in marriage and concubinage: "The traditional sources have so far been interpreted as saying the concubine was a widespread phenomenon of the 'Abbāsid era and not the Umayyad; they also claim that Umayyad society treated the concubine and her child relatively poorly. Neither argument can be sustained in the light of our prosopographical analysis." (Robinson 2013, 20-21).

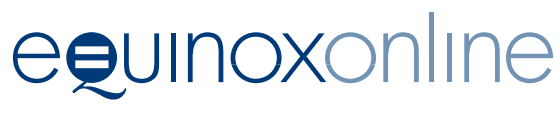


diverse elements, though not all would agree ${ }^{11}$ with Fred Donner when he calls Islam an "ecumenical" movement at its inception (Donner 2010). Both Muhammad and his successors in the leadership of the community relied for their success on the incorporation of diverse communities in a super-tribal federation, incorporating different languages, religions and cultural traditions, which were later fused together as "Arab" as a way of marking themselves off from later incorporations. ${ }^{12}$ The Muslim conquests incorporated groups such as North African Berbers on the basis of shared interests, rather than shared culture. While the Arab Muslim conquerors founded new settlements apart from the old centers of civilization; the famous garrison cities ('amșār) like Kufa, Basra, Fustāat, they did not keep themselves strictly apart from the conquered peoples: intermixing spiked massively as concubines became a key element of conquest booty (Robinson 2013).

While Christian Arab tribes had been incorporated into Muhammad's super-tribal federation, the early generations of Islamic rule after his death increasingly lead towards the crystallization of the category of "Muslim" as one among several key terms including tribal affiliation and clientage that had implications for taxation, governance and the distribution of the wealth generated by the Islamic conquests (Donner 2010; Brett 1979). These practical concerns motivated the crystallization of firmer boundaries between Muslim and non-Muslim, most famously the distinction between the lightly-taxed Muslims and more heavily-taxed non-Muslim "protected peoples" (ahl al-dhimma). However, it must be noted that the schematic simplicity of the opposition between non-Muslim dhimmi and Muslims was a classical formulation that took a while to develop, and probably always remained a theoretical construct with no determined relationship to the more complicated facts of taxation in different parts of the empire (Papaconstantinou 2008, 127-156; Sijpesteijn 2013, 49-114).

At the same time, the governmental and administrative structures of the emerging Muslim empire incorporated non-Muslim and non-Arab elites in the bureaucracy, enshrining Greek and Persian cultural, admin-

11. "Ecumenical" is a term that Aaron Hughes objects to as implying that the divisions between Judaism, Christianity and other religious communities of Late Antique Arabia were stable. (Hughes 2017, 16-17).

12. However, recent research on the period of the Islamic conquests is destabilizing older racialized dichotomies between the Arab chauvinist Umayyads and the cosmopolitan 'Abbāsids. Arguably, Islam was from its inception, based on a coalition of diverse communities. For a recent work arguing for the constructed nature of "Arab" as a unitary identity, see Webb (2016).

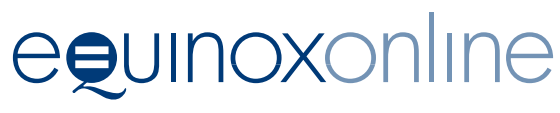


istrative and intellectual forms at the heart of the Islamic project. Thus Greek and Persian language, cultural assumptions, methods of working and networks were immediately central to the project of consolidating the transnational Muslim community. In the East, non-Muslim Persian landowners struck bargains with the Muslims and continued to rule over both non-Muslim and Muslim residents (Pourshariati 1995, 2004). In Egypt and Syria, Christian local elites, including clerics were appointed as tax-collectors over the villages which they had controlled since well before Islamic rule (Brett 1979, 501-502). The exigencies of law and governance gradually created new identities and relations between rulers and subjects. As Papaconstantinou notes,

The Islamic principle that law can only be religious law created the conditions for the gradual reification of the ahl al-dhimma and of the various religious groups that were recognised as its members. (Papacontantinou 2008, 129)

However, she urges caution, warning that this image of "self-governing groups that had their own institutions and their own designated leaders is probably ideal," and suggests that, insofar as it obtains, this ideal image relates most closely to the situation starting from the ninth century CE. Before then, "it is quite misleading to speak of "dhimmi status" or "dhimmi communities" as a given, clear and definable reality" (Papacontantinou 2008, 129).

In addition, while it is true that the creation of a distinction between Muslim and non-Muslims emerged as part of the governmental imperative to guarantee the tax-base of the conquered peoples, this same imperative resulted in a tendency to assimilate all kinds of diverse peoples into the Islamic empire, thereby pushing the boundaries as to which could be regarded as tolerated religious communities. Thus, in addition to the Jews and Christians who had been part of Muhammad's original 'umma, and who were protected as "people of the Book," the Muslims soon encountered and absorbed Zoroastrians, who became honorary "people of the Book," though not without opposition and ambivalence which is preserved in the tradition, including a statement that "[The Zoroastrians] were allowed to practice [idolatry] for the sake of the jizya [tax]" (Friedmann 2003, 72-73). Nonetheless, it continued to be possible to label Zoroastrians, or for that matter Christians, as infidel mushrikūn, depending upon the rhetorical and political requirements of the case (Bowen Savant 2013, 180-181). This encounter with the "fire-worshipping" Zoroastrians and its pragmatic solution established the principles for later accommodations with the "idolators" of India as tax-paying subjects (Friedmann

\section{eevunoxonlıne}


1986,80 ), as well as the oscillation between the urge to include tax-paying members of society or to reject them as infidels not to be tolerated. While administrators in the service of the Muslim empire sought to categorize their subjects for the purposes of control, writers drawn from this same administrative and literary elite participated in bitter struggles to define the relationship between the diverse elements that made up the imperial elites. At the level of discourse, the shu übiyya controversy epitomized, what Roy Mottahedeh has called "the cultural conflicts caused by the assimilation of diverse people into the Islamic community" (Mottahedeh 1976, 163). The central question for the disputants in this controversy was whether piety trumped descent from the tribes who originally supported Muhammad's mission. ${ }^{13}$ Early Muslims, then, had to come to terms with and make sense of the sheer facts of the cosmopolitan society which emerged from the synthesizing nature of the Islamic project from its inception, as well as the huge empire produced by the conquests. The work of making sense of these social and political processes took place in different forums and in different intellectual disciplines which produced rich overlapping and contradictory literatures: government and administration; Islamic law; theology and heresiography; scriptural transmission and exegesis and historiography. Each of these fields of enquiry structured their responses to the problems and opportunities of diverse societies in different ways. In what follows we will primarily be concerned with the overlapping fields of historiography and theology, but I will take it as read that these fields, though they followed their own disciplinary paradigms, were heavily influenced by work in other fields, and, indeed, often the work of scholars active in a number of fields. Thus the Islamic law of non-Muslim communities was an important factor in, though not determinative of governmental practice. The same legal framework provided impetus for the exploration of the theology of community present in heresiographies. These heresiographies are at the same time theological in their taxonomical interest in setting out differences in doctrine, but also historiographical, in their identification of the roots of theoretical splits

13. Motahhedeh quotes Ibn 'Abd Rabbih's (d. 328/940) characterization of the shu'ubì line as follows: "The believers are brothers, whose lives are equal in value before the law (tatakâfa'û dimẩuhum). As [Muhammad] said in the farewell pilgrimage in the speech in which he bade farewell to his community and with which he set a seal on his prophecy: "... You are all from Adam, and Adam was from the dust. The Arab has no superiority to the non-Arab ('ajamî) except by virtue of righteousness (taqwâ)." These words of the Prophet [add the shu' ûbîs] are in agreement with the words of God: "Truly the noblest among you before God is the most righteous"' (Mottahedeh 1976, 164).

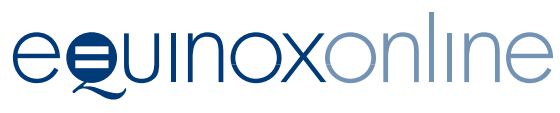


at precise moments in the history of the Muslim community. Histories of the Muslim community were heavily influenced by such heresiographical understandings of historical time, for a great impetus for writing history was making sense of the splits that had been introduced into the Muslim community. Hadith gave a voice to attempts to understand these splits, most notably the saying ascribed to the Prophet Muhammad that predicted that the Muslim community would splinter into around 73 sects, only one of which would be saved (Van Ess 2011, 7-64). Heresiographies also formed the foundations for a new discipline: that of comparative religion, which placed internal Muslim splits in relation to those in other religions (Lawrence 1976, 5-6). The development of comparative religion was both natural (for many Muslim ideas developed in active engagement with other religions) and remarkable in its extent and fertility (Jeffrey 1951). Histories of the world-the so called "universal histories" that emerged in the late ninth and tenth centuries CE-sometimes took into account the heresiographical taxonomies that compared different sects, denominations and religions with one another. Elite interest in falsafa philosophy (as opposed to kaläm philosophy or theology) and other varieties of Greek thought provided a strong motivation for the Islamic justification of the use of Greek materials within the Islamic tradition. The justification of Greek wisdom influenced theologians and heresiographers, and provided an important model for historical writing in the figure of the Greek philosopher as sage (hakim) a key category applied also to Indian wisdom figures, as we shall see below.

\section{Universal histories}

While the scholars and litterateurs active during the rule of the Umayyad dynasty had produced histories relating to the early Islamic conquests, the battle days of the pre-Islamic Arabs, and prophetic histories drawing upon biblical and extra-biblical material, the "Abbasid period saw the emergence of "universal histories," so-called for their intention to embrace all peoples, regions and periods of the world's history going back from the time of creation to the present (Robinson 2003; Khalidi 1994; Di Branco 2010). These works were both produced by independent scholars, and patronized by 'Abbasid elites but in either case they can be seen as part of the development of a self-consciously cosmopolitan outlook upon the world which sought to bring together and synthesize the intellectual achievements of earlier peoples. The concept of 'umma was at the heart of these historiographical syntheses. Historians adopted and expanded the

\section{eevunoxonlıne}


thinking implied by the Qur'ānic usage of the word 'umma, and attempted to identify the historical paths of various communities, and the extent to which they embraced or rejected God's plan for the world as expressed in prophetic revelations. While they thus intended to fit other cultures and nations into a pattern which justified Muslim salvation history, portraying Muslims as the recipients and guardians of God's last, most perfect message to mankind, they also drew heavily upon non-Muslim books, informants and eyewitness accounts of foreign lands. The use of non-Muslim sources as valid vehicles for truth was facilitated by the sociological fact of the diversity and connectedness of 'Abbasid cities like Baghdad and Basra, but also by an epistemological orientation which favoured the critical assessment of knowledge from any quarter, however potentially unorthodox. Rosenthal (1970) argued that the orientation towards knowledge was the quintessential aspect of early Muslim thought and civilization. For historians, the absorption of different sources of knowledge meant the development of a set of hermeneutic tools by which the validity of transmitted lore ( $a k h b \bar{a} r)$ could be weighed against eyewitness accounts ('iyān) (Khalidi 1975, 28-54). It is tempting to compare these epistemological developments in Muslim historiography during the era of 'Abbasid imperial expansion with the advent of early modern European historical consciousness in the age of empire and encounter. ${ }^{14}$ In both contexts, the encounter with the other necessitated a reevaluation of the relationship between empirical observation and transmitted authority in formulating the history of the world.

The encounter with other cultures and religions was channelled through a broader 'Abbasid imperial project of self-legitimation which took place within a milieu of theological debates staged between religions and sects; the translation of Greek, Syriac, Pahlavi and Sanskrit scientific and philosophical texts; and the targeted gathering of information from voyages abroad. While reported encounters (for example in the famous theological debates held between Muslims, Jews, Christians, Indians and so on) (Lawrence 1976, 75-76, 84; Van Bladel 2011, 87-88) usually resulted in the triumph of whichever Muslim perspective was hegemonic in that particular context, such encounters very clearly influenced and were

14. See, for example, the characteristics of modern history writing suggested by Bentley $(1999,6)$. He quotes Eric Voegelin in citing various factors in pushing thinkers of the eighteenth century towards new paradigms of history writing, including general scientific advances and "the discovery of the New World and the more intimate acquaintance with Asiatic civilizations."

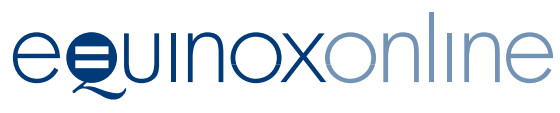


absorbed into Muslim discourses. Likewise, while the ideologies of community represented in Muslim universal histories ultimately justified the Islamic vision of history with the community of Muhammad representing the culmination of human felicity, they also provided a rich forum for the articulation of ideas about the rest of the world. This discourse explicitly employed the word 'umma, or its plural, 'umam. ${ }^{15}$ By including universal history within the salvation history of the Muslim community, the question was implicitly posed as to whether these communities had also participated in the human history of salvation, or had instead been damned to life in the darkness of idolatry, atheism and false-prophecy. If, as Qur'ān 16:36 asserted, every nation ('umma) was sent a messenger, then there should be traces of these missions in the histories and religions of the other communities of the world. Certain hadiths numbered the prophets as many as 124,000 , of which up to 315 brought a new law, thereby establishing a new religious community (Crone 2004, 10). Therefore, motivating the elaboration of the idea of 'umma was the search for origins to identify the prophetic founder of the community in the historical record. The Qur'anno-biblical material emphasized the role of prophets as the founders of communities, thereby conflating community with religious doctrine and practice. On the other hand, in material drawn from both Persian and Greek sources, the role of kings as founders of communities was prioritized above prophets, generating a conflation of king and prophet into the quasi-prophetic category of the philosopher king as founder of a community and a religious tradition. That Tabarîs universal history was named The History of the Prophets and the Kings (Tärïkh al-rusul wa al-mulük) (1986) highlights the centrality of both of these categories in defining the history of the world and its communities. Another key figure that accompanies, and is sometimes conflated with prophetic and royal community-founders is the sage (hakim), a character who comes to be equated both with wise ascetics and with philosophers. ${ }^{16}$

Within the synthesis that led to the eighth-ninth century CE universal histories, we perceive a dominant strain of Qur'ān-mindedness, but also the dominant position of Persian regnal history (mulūk al-furs) as a historiographical foundation according to whose parameters information from other regions and cultures should be assimilated. This foundation is the result of the 'Abbasid empire being located in the Persian

15. Also used was the word milla, which tends to more narrowly refer to a religion or religious community. C.E. Bosworth, "Milla," EI2.

16. See A. M. Goichon, "Hikma," EI2.

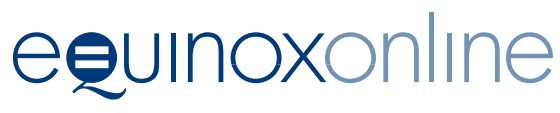


cultural zone, with the capital Baghdad being near the old Sassanian capital of Ctesiphon, as well as the fact that a significant support base for the 'Abbasids was drawn from Khurasan. However, as we see from historians like Țabarī and Mas '̄ùī, the foundational role of Persian regnal history is also justified through an appeal to its great consistency and historical coverage back to the beginning of the world (Tabarī 1986, 133-134; Mas' $\left.\bar{u} \mathrm{i}_{\overline{1}}, 1938,5\right)$, factors which were themselves due to the fact that an earlier Sasanian imperial project had imposed an unbroken dynastic succession back to the beginning of the world upon available historical materials. ${ }^{17}$ The bifurcation of Persian and Qur'āno-biblical material in telling the history of the world introduced certain contradictions that had to be reconciled, creating a fertile space for creativity in conceiving of relations between the nations.

\section{The problematic case of India in Muslim historiography}

In order to understand the theoretical underpinnings of Muslim historiography with regard to other cultures, religions and regions, the treatment of India and Indian religions serve as a particularly useful case study. The possibilities and limitations of cosmopolitan Muslim conceptions of the world as a single human community are made evident in this context because the role of idols in Indian religions tended to ensure it a place as the archetypally errant nation. So potent was the association of India with idolatry that even the pre-Islamic Arabian idolatry which was the main object of Qur'ānic opprobrium was sometimes attributed with Indian origins:

\footnotetext{
"According to an Islamic tradition, India was the first country in which idolatry was practiced and the ancient Arabian idols were of Indian origin. Indian idolatry began after Adam descended following his expulsion from Paradise on an Indian mountain called Büdh; after his death the sons of Sheth began to worship his body. Following this, a man from the sons of Cain offered to carve idols for his people so that they also would have an object of worship. He was the first man to do this. Later, in the time of Noah, the waters of the deluge washed the idols away from the Indian mountain on which they were placed, and swept them from country to country until they finally landed on the Arabian coast near Jidda. The legendary founder of Arabian idolatry, 'Amr b. Luhayy, was directed by a jinn to the place in which they were located. He found the idols and called upon all the Arabs to worship them." (Friedman 1975, 214)
}

India's association with idolatry meant that in some articulations, India was excluded from humanity's common quest for truth and meaning.

17. See A. SH. Shahbazi, "Historiography ii: The Pre-islamic period," Encyclopedia Iranica.

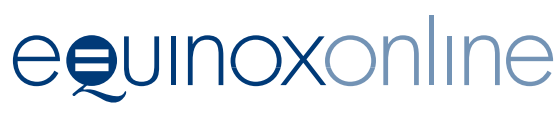


For example, in one tradition, the prophet Sulaymān was "recorded by Ibn Battuta to have come to a mountain in Sind from where he could view India but was intimidated by its darkness and turned his back on it" (Wink 2002, 1: 192). The image of the prophet turning his back on an idolatrous India gives a sense of the problematic status for Muslims of this land of idolaters, astrologers and star-worshippers.

\section{Sources for the Muslim image of India}

We can discern within the sources for the Muslim construction of India, a distinction between those based on reportage and those based on transmission of earlier lore. The bulk of information about India in Islamicate sources probably derives from transmitted lore filtered through the major literary traditions of the civilizations which the Islamic tradition absorbed: principally Greek and Persian traditions-particularly the latter which had been in constant contact with India throughout its history. Eyewitness reportage is difficult to distinguish clearly from transmitted lore, as travellers' tales often included a large component of sailors' yarns and wonderful legends of the type that fill the Wonders of India, ('Ajā'ib al-Hind) (Buzurg ibn Shahriyā 1981; Mackintosh-Smith, 2014). Nonetheless, the empirical study of the world is a marked feature of this era of historiography, and it is one which was enabled by the military expansion of Muslim power, as well as the expansion in economic and trade links that followed. The opportunities that existed for scholars to travel widely resulted in a particular epistemological orientation in the way the world was studied: Mas'ūdī explicitly defended the importance of eyewitness reports for gathering reliable information about the world $(2005,1: 10)$, in addition to reproducing the old accumulated curiosities transmitted by earlier literary and oral traditions.

\section{The Research Mission to India commissioned by Yahyyā b. Khālid al-Barmakī}

A particularly influential piece of reportage about contemporary India was gathered by an anonymous emissary after the conquest of Sind, and quoted by Ibn al-Nadim in his bibliographical encyclopedia (itself a landmark of cosmopolitan scholarship in its assemblage of the available knowledge of the known world). This report was commissioned by the 'Abbāsid vizier and de facto ruler, Yahyā b. Khālid al-Barmakī around 800 $\mathrm{CE}$, and reached Ibn al-Nadīm through the handwriting of the philosopher and polymath al-Kindī. According to Ibn al-Nadīm, Kindī's recension was

\section{eevunoxonlıne}


appended with a statement by "a certain theologian" that:

"Yahyā b. Khālid al-Barmakī sent a man to al-Hind in order to bring him back medical herbs ( $a q \bar{a} q \bar{i} r$ ) to be found in their lands, and to write down their religious traditions (adyān) for him, and so he wrote this text."

(Ibn al-Nadīm 1971, 1: 409)

The text (now lost) came to be incorporated and reworked by many other thinkers of the 'Abbasid period and beyond and was particularly valued as a source of information for comparative religions, being employed, as well as by the philosopher Kindī, by the Shi $i$ theologian and heresiographer Nawbakhtī, and the theologian Shahrastānī (d. 548/1153) (Lawrence 1976, 21-29). However, while the transmission history of this text shows that it came to be of primary interest to theologians and heresiographers for whom it allowed the triumphant claims of Islam to be enriched by a comparison with the more flawed religions of the world. Nonetheless, the report adopts a more or less objective and non-judgmental tone in its account of Indian religious sites, and the idols and religious observances associated with them, and so may be categorized as an attempt at an empirical study, little touched by the heresiographical mission to reorganize and systematize these religious phenomena.

While Ibn al-Nadim does not preserve the section on medicinal herbs, the fact that these two areas of knowledge were targeted in this mission are fascinating to consider. They suggest the inextricable intermingling of practical concerns with the search for meaning: while the religious material may have been used to satisfy the curiosity of 'Abbasid courtiers and intellectuals, and doubtless to confirm them in their religious world-view, the interest in medicaments suggests the conquest of the world and the exploitation of its natural resources on a very practical level. The interest in medicine also interestingly recalls the figure of Būrzōy, a legendary physician who sought medical knowledge in India, but returned instead with a relativistic skepticism derived from the comparative study of religion. Būrzōy's story was recounted by another 'Abbasid administrator, Ibn al-Muqaffa' (De Blois 1990). The Barmakid mission to study India, then, is important for combining a number of significant elements. Firstly, we should note the role of the Barmakids as cosmopolitan intellectuals and intermediary figures who brought knowledge about the east to the imperial capital of 'Abbasid Baghdad. The Barmakids were themselves easterners in origin, hailing from the town of Balkh in Bactria/Tukhāristān, which had been a center of Buddhism for centuries, and still continued to be so into the 'Abbasid period. An interest in Sanskrit texts and tradi-

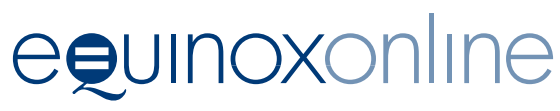


tions was, as Van Bladel (2011) has suggested, a natural outcropping of the Barmakids' position as mediators from the east located at the centre of a cosmopolitan empire. Secondly, the interest in the religious traditions of the Indians must be seen in the context of direct and relatively tolerant engagement with various sects and religions that took place in the salons of 'Abbasid Baghdad (Lawrence 1976, 75-76, 84), which allowed for the absorption of ideas from the known world, but also served to cement the centrality of the Muslim worldview at a time of self-confident cultural production in which Muslim sacred history was perfectly compatible with the search for knowledge wherever it was to be found. Thirdly, the mission to India was possible due to the background of violent imperialistic expansion, with increasing interactions made possible by the Muslim conquest of Sind (Wink 2002, 1: 7-25). It is, perhaps, no coincidence that the account transmitted by Ibn al-Nadim takes a particular interest in the wealth of the temples, which were to be a persistent focus of interest for conquerors raiding India, a material interest that was often clothed in the rhetoric of religious justification, both at the time and retrospectively (Eaton 2000, 283-319).

\section{Archetypes for the Muslim construction of India}

In Persianate histories (that is, historical narratives that draw heavily on Iranian and Persian experiences and narratives; especially those structured around the Iranian kings and heroes) a number of elements emerge as dominant. While 'Abbasid-era Muslims had numerous sources of information on India, derived both from transmitted lore and eyewitness accounts, their narratives tended to be dominated by a number of basic archetypes and topoi: the figure of the sage (often with a rationalistic message); the law-bringing king; the themes of astrology, star-worship, and idolatry. Doubtless these topoi reflect, to some extent, genuine historical information transmitted from India. However, they also had a life of their own and act as fundamental categories which shaped the way Muslim intellectuals received and interpreted new information about India.

\section{The sage as archetype}

One major opportunity for talking about India in the histories arises in relation to the conquests of Alexander the Great: his wars and relations with Indian kings, and also his interactions with Indian sages (hakim). Alexander was considered a righteous king, and, in his relations with his

\section{eevunoxonlıne}


advisor, Aristotle, he was a paradigm for the proper relations between powerful rulers and their sage advisors. It is therefore significant that in his interaction with India, Alexander is depicted as having been impressed by the wisdom of Indian sages, thereby admitting Indian sages into the category of wise advisors to a righteous, divinely-sanctioned ruler (Tha'ālibī 1979, 421-431). India was thus famous for its sages, and these archetypes must be seen to originate, at least to some extent, in paradigms emerging from India itself. Perhaps the most famous example of an Indian sage whose exploits were domesticated within the Muslim context was the Buddha, whose name becomes Būdhāsaf or Yūdhāsaf in Arabic and Persian sources. The Buddha's story was domesticated (probably via Manichean sources) to the monotheistic context by stripping the young world-renouncing prince of his Buddhist trappings and recasting him as a more generic ascetic (Abuladze 1966, 19-41; Gimaret 1971). Nonetheless, the Islamic tradition did not forget his role as the founder of a religious community, as we will see in Bīrūnì's account in the Âthār, below. Būdhāsaf became an important model for the Shi'a who identified with the story of the persecution of a boy of noble blood at the hands of an unjust king. Thus, for example, Ibn Bābūya includes the story of Barlām and Yūdhāsaf as an extended sixty-page excursus in his treatise on the Occultation. Ibn Bābūya's use of an Indian legendary figure is facilitated by the distinctively Shi' $i$ vision of history in which, at all times and in all communities, a small group accepts the message of a prophetic figure, though they are surrounded by a misguided and irreligious majority ('āmma), usually synonymous with the Sunni status quo in the era of Muhammad. In this context, the wise sage is at odds with the community around him. The true religion belongs only to the few (Ibn Bābūya [1975], 577-638). This enthusiastic appropriation of the figure of the sage Būdhāsaf as a quasi-Muslim hero is in sharp contrast to Bīrūnī's treatment of Būdhāsaf in his Āthär (see below), but it fits within a larger pattern of accepting the sage-philosopher-ascetic figure as a legitimate model for the thought and actions of Muslims, in spite of the pagan context from which they spring (whose idolatry, of course, is roundly criticized in such narratives).

In addition to acting as a model of asceticism, the idea of the sage was adopted by thinkers who upheld the rationalistic pathways to truth as opposed to or in addition to the guidance of revelation. In some accounts, for example, Būdhāsaf is identified with the astrologer-king who brings astrology to India (Pingree 1968, 4-5). The above-mentioned case of Ibn al-Muqaffa"s physician (also hakìm) Būrzōy is an extreme case of a

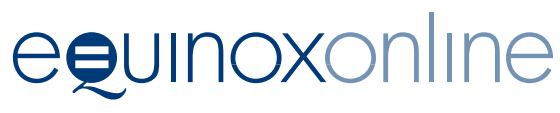


rationalistic skeptic whose search for knowledge takes him to India. As De Blois (1990, 32-33) notes, Būrzōy unites Hellenistic philosophical skepticism and Indian ascetic renunciation of an inconstant world. The central pivot of Būrzōy's skepticism is a relativistic equalization of the competing claims of the different religions, which was anathema to Muslim theologians of various orthodoxies (De Blois 1990, 26). In the case of Ibn al-Muqaffa"s sage Būrzōy, then, India comes to be associated with a cosmopolitan rationality which equalizes claims to articulate the truth, and (for many readers), represented a dangerous and perhaps heretical questioning of revealed religion. Bīrūnī, for example, sees Ibn al-Muqaffa"s citation of the Būrzōy story as a way of softening up those weak in faith to make them receptive to Manichean propaganda (De Blois 1990, 26-30). For Ibn al-Muqaffa', however, Būrzōy's skepticism seems to be equated with wisdom. The Būrzōy story was not the only figuration of India as a locus of skeptical thought: among Muslim theologians (mutakallimūna) the Indian religious thinkers known as the Barāhima came to be the archetypal representatives of a skeptical, rationalistic argument for the denial of prophecy. ${ }^{18}$ For Bīrūnī and Shahrastānī, as we shall see, the Indian sage is a philosopher comparable to the Greek philosophers of antiquity. The extremely flexible nature of the idea of sage, allows it to represent a number of different orientations, including ascetic, philosopher, doctor, scholar, theologian and skeptic, thereby offering very different thinkers a space in which to consider Indian contributions to philosophy and religion positively.

\section{The philosopher king as archetype}

The archetype of the philosopher-king or law-bringing king accompanies the sage as a key frame of reference for treatments of India. These accounts provide a framework in which Indian thought and religion can be made sense of as part of the prophetic history of the world. In both Ya'qübì's History and Mas'ūdì's Murūj al-dhahab, to take a pair of prominent examples, instead of what we might expect to find-a sustained polemic against the idolatrous Indians-India is, in fact, treated as the origin of much true knowledge which the world continues to benefit from. In addition, through the figures of the sage and the philosopher king, Indian religion

18. There is no consensus on how the Barāhima came to be the archetypal rationalist prophecy-deniers, but a definitive early statement of this idea came in Ibn al-Rāwandī's Kitāb al-zumurrudh who used it to voice skeptical anti-prophecy arguments in the mouths of the Barāhima. (Lawrence 1976, 78-88; Stroumsa 1985, 229-241).

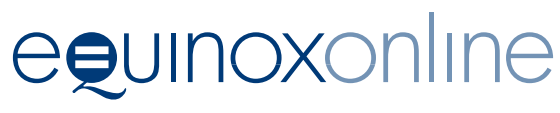


is portrayed as historically comparable to the more canonical religions usually understood as the religions of the book (those religions possessed of a scripture which has its origins in a true revelation from God to man, albeit since corrupted by time and human frailty). Like them, India is seen as part of the common story of successive cycles of revelation followed by corruption. In this way, the fighi paradigm of clearly separating between Muslim, protected monotheist dhimmi and infidel mushrik is paralleled by a contradictory model which collapses the distinctions between monotheists and infidels as distinct communities.

In the History of Ya qūbī, one of the earliest Islamicate universal histories, the author treats India as one among many historical communities whose histories and legends he recounts, including the stories of the kings of Greece, Persia, Syria, Babel, China, the Berbers and Ifrīqiya, Ethopia, Yemen and so forth. His account is notable in its use of native informants, rather than purely Arabic or Muslim legendary sources (Robinson 2003, 136). In Ya 'qūbì's account, the sheer fact of Indian wisdom is treated prominently. His account of the Kings of India begins with an acknowledgement of the great scientific achievements of the Indians, and their progenitor, the wise king Brahman, ${ }^{19}$ who is depicted as the original source of this knowledge: "And he was the first to speculate about the stars, and the science of astronomy was taken from him" (Ya qūbī [c. 1980], 1: 84). There follows a list of the great books that were derived from Brahman's original contribution, including books like the Ptolemy's Almagest. Following this auspicious start, the problems of India are said to have arisen when the primordial kingdom of Brahman splintered, but nonetheless, we are told, "They were people of philosophy (hikma) and knowledge (ma'rifa) and intellect ('uqūl), surpassing the other nations ('umam) in them" (1:84). In their wisdom, the Indians agreed to reunify and appoint a king, Zāriḥ, to rule over all of them once again. Zārih proves his greatness by going on a campaign of conquest, until he tries to conquer Banū Isrā'îl: "And Banū Isrāîl cried out to exalted God, and God gave Death dominion over Zārih and his army, and he returned to his land." Here, then, we see a curious mixture of positive and negative elements associated with the primordial India: it is recognized as the wellspring for knowledge of the stars (a realization that is grounded a memory of the transmission of knowledge from

19. It is hard to surmise how Ya qūbī might have vowelled this name: perhaps Barahman to avoid the initial consonant cluster. I have used the transliteration "Brahman" to achieve some kind of consistency and to approach the presumed Indian originals "Brahma" and "Brahman."

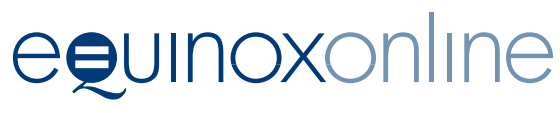


India to Iran in antiquity), ${ }^{20}$ and Indians are recognized as truly wise, yet when faced with the religion of the monotheistic Israelites, the power of God is invoked to crush the Indians. This fits the familiar pattern of impious outsiders threatening the monotheists, and yet there is a notable lack of judgmental opprobrium targeted at the Indians. The Indian kings are praised as intelligent and wise (hakim).

Indian sages also figure prominently in Ya'qūbī's narrative, participating, for example, in a theological debate in the famous story of the invention of backgammon and chess. In this story, backgammon is said to represent the cosmos, and the workings of the game symbolize the operation of the heavens in predetermining human destinies. After its invention, backgammon becomes a great success with the king and the people of India (1: 90). This situation persists until a new king, Balhit comes to power who disapproves the deterministic theology and star-worship implicit in the game of backgammon and asks "Is there any man who remains in the Brahmite ${ }^{21}$ religion?" A man is accordingly identified who is said to be "possessed of intellect and religion (lahu 'aql wa din)" (1: 90). A new sage is sent for, who corrects the pernicious influence of the game of backgammon with the game of Chess which itself contains a parable: as a war-game, Chess indicates the importance of one's active engagement to shape one's own fate: “Then the sage (hakim) said: There is nothing nobler than war, for in it the virtue of ordering one's affairs is made manifest, as well as the virtue of good council, and steadfastness, and precaution..." (Ya'qūbì [c. 1980], 1: 91). The king gathers the people of his kingdom and adjures them to contemplate the new game, asserting that,

We know that there is nothing living, articulating, thinking, laughing, reasoning, except mankind. Thus, everything that is in the world pivots around mankind, for the Creator created the cosmos along with everything in it [i.e. the celestial bodies] for mankind, so that he may know through it what he needs to know by way of time and seasons. (Ya'qūbī [c. 1980], 91)

Here, then, the pairing of an Indian sage and the philosopher king is approvingly depicted as supplanting the deterministic astrological beliefs and practices which are often associated with India, with a theology that

20. For the evidence that Sasanian astrology was deeply influenced by Indian astrology, see Pingree (1963).

21. This adjective could perhaps be translated as "Brahmin," however, in translating it as "Brahmite" I suggest that it is referring back to the progenitor king Barham mentioned at the beginning of the chapter, rather than referring to Brahmins who were contemporary to Ya'qūbī or his informants.

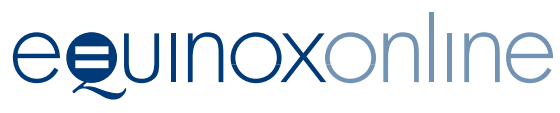


places more emphasis on human agency. This salutary insight into the truth appears to have a fully human origin, achieved through reason, rather than direct revelation. There is no suggestion that as Indians, they are restricted from insights into truth or the nature of the cosmos.

To conclude his account of the Kings of India, Ya 'qūbī returns to a remarkably positive summary comment on the achievements of the Indians:

"And the Indians are people of wisdom/philosophy (hikma) and rational speculation (nazar) and they supersede people in all branches of wisdom and their statements on the stars are the most accurate of statements, and their book on this is Kitäb al-Sind-hind, from which is derived all the sciences which the Greeks and the Persians elaborated." (Ya'qūbī [c. 1980], 1: 94)

After enumerating their scientific and intellectual achievements, Ya'qūbī briefly mentions the topic of idolatry:

"And the religion of the people of Hind is al-Brahmiyya and it includes the worship of idols ('așnām) and they have various kingdoms and different kings due to the extent of the country and its length and width..." (Ya'qūbī [c. 1980], 1: 94)

Explicit condemnation of idolatry was superfluous to Muslim audiences. Nonetheless, it is striking how this mention of contemporary idolatry appears almost neutral, sandwiched between an enumeration of the scientific and intellectual achievements of the Indians and a list of the contemporary kings of the various regions. While Ya 'qūbì's account subordinates Indian history to the monotheistic tradition (most explicitly in the story of Zārih's invasion of the Israelites), the tone is remarkably apolemical: India is depicted as a partner in humanity's quest for truth; a legitimate source of scientific and philosophical insight.

Mas'ūdī's (d. 956 CE) orientation towards the history of India follows similar patterns to Ya'qūbī's, mentioning many of the same episodes, though, as we have mentioned, Mas' üdī himself had travelled to India and was therefore and more fully informed by eyewitness accounts and contemporary reportage (Ahmad 1960, 97-112; 1954, 510-512). He was also very interested in the history of religious groups, authoring several works of disputation and heresiography, as we can see from those works in the list he gives of own works, which clearly suggest a heresiographical-theological framework from their titles (Naẓm al-'adilla fī ușūl al-milla, and al-Masāil wa al-'ilal fī al-madhāhib wa al-milal) (Mas'ūdī 1938, 3). As Tarif Khalidi notes, Mas' ūdì's "oral information was gleaned from debates as well as interrogations... Mas'udi records that he held public debates with Christians, Jews and Khurramiyya, in Iraq, Palestine and Persia" (Khalidi $1975,3)$. In reading his account of the kings of India, we can detect the

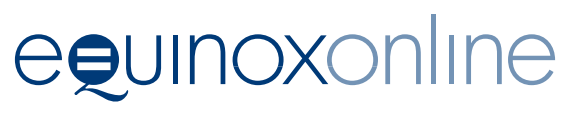


influence of heresiographical frameworks, to a greater extent than in Ya'qūbì's history.

As in Ya 'qūbì's history, Mas 'ūdì's account of the history of India in Murūj al-dhahab depicts a philosopher king, Brahman, as laying down foundational rules and doctrines, including the foundations of the sciences of astronomy and astrology that were adopted by the Greeks, followed by political fragmentation and religious and intellectual decay. Brahman is regarded as the primogenitor of the group known as the Barāhima: "His descendants are called the Barāhima up until our own time, and the Indians venerate them, for they are the highest among their castes (ajnās) and the most noble of them" (Mas' ūdī 1938, 1: 62). While Mas' ū ${ }^{1} \overline{1}$ assimilates Brahman to Muslim models of prophetic revelation, he does not do so by the simple method of identifying Brahman with a Muslim prophet. Mas'ūdi mentions, but is skeptical of theories which had attempted to force Brahman into the sequence of Qur'āno-biblical prophets:

"A disputation exists regarding Brahman. Some of them claim that he is Adam (AS), and that he was a Prophet (rasūl) sent by God (AJ) to India. And some of them say that he was a king as we have mentioned, and the latter opinion is more widespread." (Mas'ū ūī 1938, 1: 63)

While Mas'ūdī does not accept the incorporation of Brahman directly into prophetic history, it is notable that he addresses such theories as plausible. The existence of such theories show us that some people had attempted to splice Indian foundation myths with Islamic prophetic history. This attempt is comparable to Persian attempts (also rejected by Mas'ū $\bar{d} \bar{i}$ and Tabarī) to conflate the Zoroastrian first man, Gayomard, with Adam. Intrinsic to the task of producing a universal history was the assessment of purist versions of communal histories against hybridizing models. (Bowen Savant 2013, 31-60; Tavakoli-Taraghi 1996, 157-161). While Mas'ūdi argues on the basis of the weight of consensus to reject the idea that the Indian founder figure, Brahman, was a prophet within Qur'āno-biblical tradition, he nonetheless assimilates his Indian historical material to a very Muslim vision of the history of the communities of the world. In this vision, the truth is revealed to the nations of the world, as articulated in Qur'àn 16:36. However, the revelation of the truth is then followed by gradual loss and corruption of this truth, thereby explaining the existence of divergences from Muslim doctrine within the Jewish and Christian traditions (See "Tahrîf," EI2). In Mas'ū ü's version of this scheme, he implicitly gives great importance to rationalistic insights into the truth. In his narrative on India, not only Qur'āno-biblical prophets,

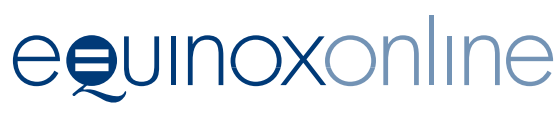


but also philosopher-kings of other historical traditions appear as legitimate bringers of truth and law to their communities. In this way, he draws upon the identification of India with science and philosophy that we see in Ya'qūbì and other writers.

In effecting the association of India with Muslim models, Mas'ūdī uses terminology familiar from heresiographical literature. From the beginning of Mas'ūdī's chapter on India in Murūj al-dhahab, he makes it clear that the Indians were, from the start, participants in the legitimate history of religion: "A group of the people of science and investigation mentioned... that the Indians in olden times were the sect (firqa) in which was righteous practice and wisdom (al-ṣalāh wa al-hikma)" (Mas ūdī 2005, 1:61; Ahmad 1960, 99). Given this opening, if Indian religion ends up in idolatry, then, the narrative must be one of corruption of religion, rather than an essential intrinsic divide between them and monotheists. Thus, after the account of various reigns of the ancient kings of India, their philosophies and religious opinions and their cultural and scientific achievements, Mas'üdì's account of the ancient kings closes with a suggestion of the gradual corruption of the pristine Indian religion into its present state. In the reign of King Kürash, the king is said to have,
"Innovated for the Indians [new] doctrines in their religions (ahdatha li-al-hind 'ärä' fi al-diyānāt), according to his opinion about what would benefit the age (șalăh al-waqt), and what the people of the age could bear regarding religious responsibility (taklif), and he departed from the doctrines of his forebears (kharaja 'an madhāhib man salafa). (Mas'ūdī 1938, 1: 65; Ahmad 1960, 104-105)

The language here links the evolution of a religious community with the semantics of the Muslim theologians' conception of religious responsibility (taklīf). The terms for religious sects: firaq, 'āra $\bar{a}$ ' and diyānāt are those familiar from Muslim heresiography, and the verb innovated ('ahdatha) recalls debates over what might constitute beneficial and malicious innovation (muhdath/bid'a) in law. ${ }^{22}$ The evocation of religious responsibility recalls central topics of disputation about free-will and justice familiar from the discourse of the kaläm theologians, especially the theodicy-fixated mu'tazila, with whom Mas'ūdī appears to have aligned himself. ${ }^{23}$ The passage implies that Kürash acts to relieve his subjects of an overly burdensome responsibility which they are not capable of bearing. However in the landscape of kalām debate on the subject of taklif, ${ }^{24}$ we must adjudge

22. J. Robson, "Bid'a" EI2.

23. Charles Pellat "Al-Mas'ū d̄̄", EI2.

24. Daniel Gimaret, “Takliff, EI2. 
Kūrash to have erred in attempting to relieve his subjects of obligations

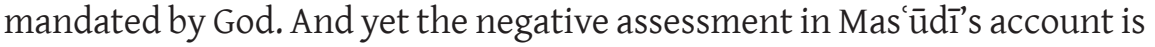
again implicit, rather than explicit. The Indians of the generation of King Kürash, are depicted as engaged in disputes comparable to the disputes within earlier generations of Muslim thinkers. While there are no unambiguous cues to assign a clear moral valency to Kürash's innovations, the language implied that this was a milestone in the corruption of the beliefs of the Indians.

Following Kūrash, Mas ū $\bar{d} \overline{1}$ 's narrative of fragmentation and corruption of religion proceeds apace: "When this king died, the Indians became divided in their [religious] opinions ('ärä'), and different parties formed and the generations were generated and every leader went off on his own way" (Mas'ūdī 2005, 1: 65-66). In this way, the Indians are seen to fulfill what appears to be a universal pattern in the history of religion: fragmentation and disunity after the initial revelation. Elsewhere Mas ū $\bar{d} \overline{\mathrm{l}}$ mentions that after the appearance of seven sages (hakim), the Indians split into further groups, ultimately generating seventy sects (Mas'ūìi 2005, 1: 62-63). This, too, corresponds very exactly with the history of the Muslim community as understood by Muslim heresiographers. The story of religious foundation followed by fragmentation into seventy sects recalls the famous hadith (extant in several versions) in which the Jewish, Christian and Muslim religions each received prophetic revelation after which they became fragmented into around seventy sects (Van Ess 2011, 1: 7-58). In this way, India is presented as being integrated into the cyclical patterns of monotheistic history, in which a founder figure, Brahman, brings a religious law, followed by gradual political and sectarian fragmentation through which access to the truth is diminished. This is a process which does not distinguish the Indians from the Muslim community, but rather is shared by the Muslim community, albeit the final outcome may be understood to be different. Here, then, we appear to witness the paradox identified by Josef van Ess, in which the heresiographical framework, although founded upon the exclusivist assumption that there is just one "saved group" (al-firqa al-nājiya), nonetheless quarantines the conflicts between Muslim sects by fixing them into a crystallized interrelatedness which acknowledges all groups as somehow belonging to the same religious tradition (Van Ess 2011, 1: vii-x). Mas ūdī implicitly adds Indian religion to this quarantined web of human endeavor and weakness. The heresiographical assumption that only one group holds privileged access to the truth does not preclude the fact that all groups do, in fact, have some

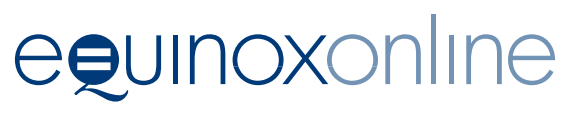


relationship with the truth. While this erects hierarchies it also creates boundaries that are porous. In showing Indian religion to fit into a similar heresiographical and historical paradigm as the Muslim community, with the Indian philosopher-kings positioned as rationalist quasi-prophetic revealers of truth, India is effectively incorporated into the community of nations: a community that encompasses both truth and error.

\section{The doctrinal elitism of comparative religion}

While Mas' ūdī's account of India in Murūj al-dhahab is a history influenced by theological categories, the Indian studies by Bīrūnī and Shahrastānī are more centrally driven by the comparison of doctrinal typologies. Both Bīrūnī in his Tahqīq mā li al-hind (often known simply as his India or Indica) and Shahrāstāni in al-Milal wa al-nihal use doctrinal taxonomies to erect explicit hierarchies of religious truth. One might expect the erection of such hierarchies to result in a sharp differentiation between Muslim and non-Muslim religious traditions, and while this is true to some extent, there is a contrary motion to uphold true models of religious thought and behaviour regardless of which tradition it is found in: all religions and sects appear on a great continuum.

\section{Bīrūnī's assimilation of Brahminical religion to Muslim paradigms}

Bīrūnìs study of India and Indian religion is unique in the level of its engagement with Sanskrit primary sources and Brahmin informants. ${ }^{25}$ Bīrūnì's engagement was made possible by Ghaznavid empire-building violence, but also by the theoretical engagements with India and Indian religions made by previous generations (as represented, in the current discussion by the efforts of Yahyā b. Khālid al-Barmakī , Ya'qūbī and Mas' $\bar{u} \overline{1}$ ) who had made the study of other traditions both possible and desirable.

It is interesting, then, to note Bīrūnī also enunciated a negative assessment of Indian religion in his comparative analysis of chronology and calendrical systems, al-Āthār al-bāqiya. In contrast to the positive assessment of the figure Būdhāsaf in accounts by Ibn Bābūya (1975, 577-638), Abū Mashar (Pingree 1968, 4-5) and the Ikhwān al-Ṣāfā (Almutawa 2013, 80-133), Bīrūnī in the Āthār rejected the assimilation of Būdhāsaf

25. In addition to his summary of Brahminic religion and philosophy in the India, he had also earlier translated an Indian philosophical text from Sanskrit into Arabic, the yogasūtras of Patañjali, as Kitāb Bātanjal. Bruce Lawrence, "Bīrūnī, Abū Rayhạn, viii, Indology," EIr.

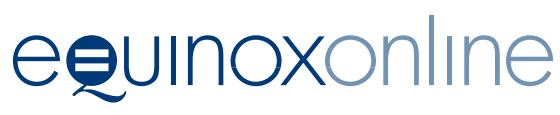


to Islamic models. Bīrūnī instead counts Būdhāsaf among the archetypal false prophets who established religious traditions or communities on false grounds. In general, what Bīrūnī says of India in Āthār conforms to a more purist, anti-syncretic dichotomy between the people of the book (religions of prophecy and revelation) and the idolatrous others. ${ }^{26}$ Within this scheme, Indian religions are referred to among the religions of the false prophets, and Būdhāsaf, is mentioned as the first among the false prophets:

The first mentioned [of the pseudo-prophets] is Būdhāsaf, who came forward in India after the 1st year of Tahmurath. He introduced the Persian writing and called people to the religion of the Șābians. Whereupon many people followed him. The Peshdadhian kings and some of the Kayanians who resided in Balkh held in great veneration the sun and moon, the planets and the primal elements, and worshipped them as holy beings, until the time when Zaradusht appeared thirty years after the accession of Bishtasf. (Bīrūnī 1879, 186)

The foundation of a religious community does not, in itself, presuppose righteousness: Būdhāsaf is understood to have founded a community of error. In this passage, using legendary-historical data on the life of Būdhāsaf, Bīrūnī also introduces an implicit theological taxonomy which allows him to conflate the religion of Būdhāsaf with that of the Șābians (as did Shahrastānī in the following century), because both Șābians and Indians were known as archetypal star-worshipping religions (Lawrence 1976, 50-51, 188-189). Here, an implicit heresiographical taxonomy is at work which assumes that doctrinal similarity (the worship of astral bodies), is tantamount to being of the same religious community ("the religion of the Sabians"). In spite of his negative assessment of the false religion of the community believed to have been founded by Būdhāsaf, then, Bīrūnī applies a heresiographical taxonomy to the history of religions which equates peoples who share similar doctrines. In his India, however, this taxonomical framework results in an assessment of the religion of the Brahmins as conceptually comparable to Islam. While the Bīrūnī of the Āthār is content to make clear boundaries between prophets and false prophets, his India was a project of a very different nature, in which he explicitly strived to make the alien Indian philosophical and cosmological categories intelligible to his Muslim and monotheist audience.

The different nature of the two works may also owe something to the circumstances of their production. Bīrūnī started his Āthār during his tenure as a court scholar in his native Khwārazm, though he updated it

26. G. Vajda, “Ahl al-kitāb," EI2.

(C) Equinox Publishing Ltd. 2019, Office 415, The Workstation, 15 Paternoster Row, Sheffield, S1 2BX

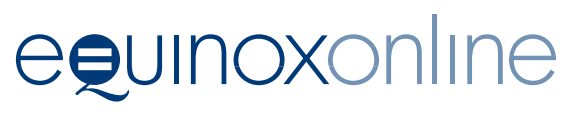


through his life. His India, on the other hand, was written when Bīrūnī was working at the Ghaznavid court, perhaps as an astrologer. ${ }^{27}$ The ruler, Mahmūd of Ghazna, had imperial ambitions involving rapid expansion to create a large empire, including raids into the wealthy north of India which had receded from Muslim control since the original conquests of Sind in the eighth-ninth centuries CE (Wink 2002, 1: 192-218). In addition to his expansionist policy, which was directed equally against his Muslim neighbours, including a "heretical" Ismaili Muslim kingdom in Northern India, these raids were also motivated by the prospect of huge financial gain. However, Mahmūd certainly also garnered prestige from his stance as a Muslim ghāzi king, famous for smashing idols at the temple of Somnath, ${ }^{28}$ which continued to burnish the reputation of his dynasty after his death, being the subject of a court elegy upon his death by the poet Farrukhī (Bosworth 1999, 43-49). Bīrūnī's project in the India, though very different from that of Mahmūd, then, must be seen as having been facilitated by Mahmūd's incursions into India which created a wide range of direct interactions with Indians.

In the India Bīrūnì displays a great deal of scorn for Indian philosophy, cosmology and science. The best he can say of them is that they contain a mixture of pearls and dung (Bīrūnī 1958, 12-13; 1888, 25). Nonetheless, the very apprehension of "pearls" among the dung of Indian idolatry is a crucial enabler for a cross-confessional mode engagement with another intellectual tradition. In order to assess an alien system of thought, Bīrūnī applies a universalizing theological taxonomy in which prophecy and idolatry are key touchstones. As in his earlier treatment of the Būdhāsaf's Indian followers as belonging to "the religion of the Sabians," in his India, Bīrūnī employs doctrinal similarities (rather than genealogical commonalities) to serve as the basis of the equation of one tradition and another. Thus, in a radical move, Bīrūnì is able to say that Indian elites are monotheists. After mentioning that the beliefs (itiqa $\bar{d}$ ) of the elite and the commoners differ in every place and time, he writes, "And the beliefs of the Indians in God (allāh) are that he is the One, the Eternal, with no beginning nor end, willful in his actions, all-powerful, wise, living and life-giving...not resembling anything, and with nothing resembling Him" (Bīrūnī 1958, 20). This statement of the basic creed of the Indians has clear and dramatic parallels to God's Qur'änic self-description, specifically with reference to the central Islamic precept of tawhīd, "monotheism" (see Qur'ān 112; 42: 11).

27. C. E. Bosworth, "Bīrūnī, Abū Rayḥān i. Life," EIr.

28. C. E. Bosworth, "Mahmud b. Sebüktegin," EIr.

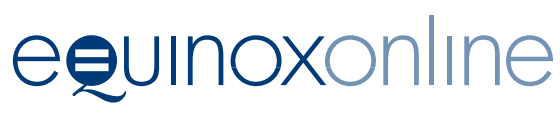


As for the idolaters amongst the Indians, these are merely commoners who yearn to have a concrete realization of their objects of worship. In another passage, Bīrūnī points out that Indian commoners are comparable to the commoners among the Muslims, who would also leap at the chance to worship a concrete representation of Muhammad or the Ka'ba (Bīrūnī 1958, 53; 1888, 1: 111. For similar instances see Bīrūnī 1958, 15, 19; 1888, 1: 31, 39). In doing so, Bīrūnī employs a theological typology that appears to draw closer connections between the elites of the two religious communities, than between the elite and the idolatrous commoners. Humans are seen as part of a common community striving for truth, but only those with education, experience and logical discernment are able to achieve this truth. The elite, therefore, have a responsibility to apply appropriate doctrines, laws and customs which limit, rather than conceding to, the pressure of popular beliefs which lead to anthropomorphism and idolatry.

If rational people can achieve monotheistic truth themselves, as seems to be the implication of his acknowledgment of the monotheism of the Indian elites, then what of prophecy? Bīrūni certainly does not reject prophecy, nor does he explicitly embrace a Fārābian down-grading of prophecy as being merely a representation of the truths of philosophy for the common people (Fārābī 2005, 1-26). In a passage praising Socrates, and alluding to Athenian society's opposition to his ideas, Bīrūnī implies that the non-prophetic apprehension of the truth is simply extremely rare in human history, and its insights are less perfect than prophetic inspiration (Bīrūnī 1958,12, 53-54 ; 1888, 1: 24-25, 1: 111-112). Given his rejection of a figure like Būdhāsaf in the Āthār, does Bīrūnī admit a prophetic or quasi-prophetic genealogy of Indian religion in the way that Ya'qūbi and Mas'ùdī and their informants hint at? The answer is complicated by the fact that when Bīrūnī discusses prophets in the India, he is referring to their role within a cosmological typology of the mediation of divine guidance in human affairs. Thus, he is not primarily interested here (unlike in the Äthär) in prophets as historical founder figures. His contribution in the India is a doctrinal taxonomy, rather than a historical genealogy of prophecy. Given this provision, we can identify moments at which Bīrūni clearly depicts Indian figures to equate to the Muslim concept of prophet, at least as far as they fulfill his conceptual typology. In doing so, he is not bound by linguistic usage, but rather constructs a typology based on cosmological function within the belief system. Bīrūnī makes the point that sometimes linguistic usage might disguise rather than illu-

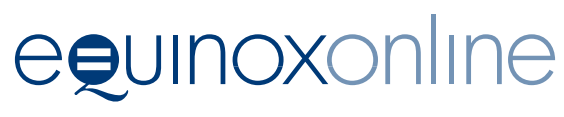


minate theological conceptions. As an example, he cites Muslims, Jews and Christians who apply the words "Lord" and "Father" to the divinity without necessarily thereby intending an anthropomorphisation of God. In the same way, Bīrūnì's description of Indian religious entities places linguistic usage on one side in order to understand them in terms of their place and function within the Indian cosmology. ${ }^{29}$ This provides Bīrūnī with the conceptual foundations to break with previous heresiographical descriptions of Indian religions: Bīrūnī discovers Indian cognates for both prophets and angels, in contrast to the common understanding of Muslim kalām theologians that the Barāhima are the archetypal deniers of prophecy.

In contrast to some other Muslim writers, Bīrūnī does not, in the India, make a significant effort to engage with debates about supposed prophetic or quasi-prophetic progenitors who correspond with the figures of the Indian pantheon. This is because he is not here embarking on a synthesis of traditions as were the universal historians, but rather a study of a distinct tradition. He does not assume that the characters present in Muslim history must appear in Indian traditions, but rather is motivated to compare the ideas in each system. Thus he translates the Indian system of thought into terms intelligible to himself and his readers, without ruling on explicitly on the divine or non-divine origin of the ideas. In this way, Bīrūnī discusses the idea of direct divine inspiration without a mediating prophet, drawing a parallel between the claims made by both ancient Greeks and Indians for the divine inspiration of their laws:

And this was the situation with [the ancient Greeks], and the state of the Indians is similar, for they see the divine law ( $\operatorname{shari~}^{-} a$ ) and its usages (sunan) as issuing from "Rishshis"; the sages (hukamä) who are the leaders of religion, rather than from the prophet-that is Nārāyan [Nārāyaṇa], who comes in human form when he comes, and never came other than to cut off an evil substance which overshadows the world, or for the mending of some occurrence, but never to change anything about the laws (sunan). For [the Indians] only act according to [laws] as they find them. For this reason, they came to consider prophets as superfluous with regards to the institution of law and acts of worship (al-shar' wa al-ibāda), albeit they need [prophets] to act in the good interests of created beings (mașālih al-barriyya). (Bīrūnī 1958, 51-52; 1888, 1: 106-107)

Here, then we see an emendation of the theologians' stereotype of Brahminical rejection of prophecy. Instead of rejecting prophets outright,

29. We might compare Bīrūnī's prioritizing of concept and function within a system as opposed to linguistic usage and indigenous categories, to Durkheim's functionalism (Durkheim 1995).

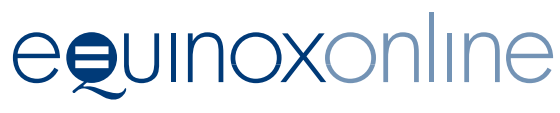


Bīrūnī here identifies their prophet as Nārāyan (Nārāyaṇa), ${ }^{30}$ but his role is not the bringing of laws, but the rectification of events in the created world, perhaps to be understood as corresponding to the model of the Islamic Mahdī or Shi'i Imam. There are some complications to this, for Nārāyan is elsewhere described as an impersonal cosmic force (Bīrūnī 1958, 46; 1888, 1: 94), or its incarnation in human form (Bīrūnī 1958, 62; $1888,1: 129)$. Elsewhere God's religion (dìn allāh) is described as Nārāyan's (Bīrūnī 1958, 64; 1888, 1: 132.). Such complications as this are doubtless what Bīrūni refers to when he talks of the confusion of Indian religious ideas. The identification of Nārāyan as a prophet is noteworthy in that it marks a breach in the Islamic heresiographical trend of identifying the Brahmins as the archetypal deniers of prophecy. However, it is not very prominent in Bīrūnì's overall treatment of Indian religion.

The significance of sages in Bīrūnì's description represents a factor of continuity with earlier readings of Indian history and religion we have seen, in which the wise sages play a uniformly important role. Thus, in the quotation above, it is the sages, not a prophet, who are responsible for the elaboration of the divine law ( $\operatorname{shari}^{-i} a$ ). Earlier, the revelatory role of sages is compared to the direct revelatory role of the divinity. In a dialogue about the nature of God, Bīrūnì quotes a dialogue from the Patancalī, which addresses the distinctively Muslim question of God's attributes (șifāt). In the dialogue the questioner asks: "Do you describe God as having the attribute of speech?" To this it is replied that, "Seeing as He is Knowing, he is necessarily speaking."

"The questioner said: "And if He is Speaking due to His knowledge, then what is the difference between Him and the Wise Sages (al-'ulamä' al-hukamä') who spoke due to their knowledge."

The respondent said: the difference between them is Time. For [the sages] were knowing in time, and only spoke after a time in which they had been neither knowing nor speaking. They transferred their knowledge to others through speech, and their speech and their acquisition [of knowledge] was in time. However divine matters have no connection to time. God (praise Him) is eternally knowing and speaking. It is he who spoke to Brāhm and the other progenitors $\left(a w \bar{a}^{\prime} i l\right)$ in numerous ways. Amongst these ways was the sending down to him [i.e. Brāhm] of a Book; the opening of a door (bāb) as an intermediary to Him; and those whom He inspired (awhāa) with the knowledge of Him.

(Bīrūnī, Tahq̣īq, 13; Bīrūnī, 1: 28)

30. Nārāyaṇa is a deified sage Narayana (who came to be identified with Lord Vishnu). In some creation stories he is involved in the creation of the Universe. See "Hinduism" and "Pancharatra" In Encyclopedia Britannica.

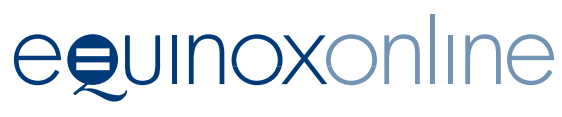


Bīrūnì's translation of this passage employs the familiar language of Islamic theology. The conception of God as knowing and speaking eternally are ideas that had been vigorously debated by earlier generations of Muslim theologians. ${ }^{31}$ The various mechanisms by which entities in the world receive divine knowledge are also familiar from Muslim discourse: Brahma is depicted as receiving a book as a revelation from God, ${ }^{32}$ in parallel to the revelation-receiving prophets. The use of the word awhā echoes the developing terminology of revelation. ${ }^{33}$ The opening of a door is ambiguous but in addition to its literal meaning, it evokes the Shici conceptions of an intermediary with the Imam or the divine (Khașīi 2007). Sages have a place within this system as legitimate articulators of the truth, albeit bound by time and materiality. Bīrūnī's Muslim readers would immediately have recognized this passage to represent Indians engaged in the same debates as their own theologians. The sense of a common theological playing field would have been strengthened by the depictions of the wise Indian sages already present in the universal histories we have encountered.

The figure of Brāhm/Brahman, who is so prominent in earlier Muslim reports, proves difficult for Bīrūnī to satisfactorily categorize. In the quote above Brahman appears as the recipient of God's speech: thereby corresponding either to the role of Muhammad as inspired prophet, or to Gabriel, the angelic figure who brought the prophet his revelations. Elsewhere, indeed, Brāhm and other divine entities of the Hindu pantheon are glossed as "angels," in another place, Brāhm is glossed as "the force known as Nature (țabī'a)" (Bīrūnī 1858, 76; 1888, 1: 100-101). Brāhm is also described as a "first cause," being understood as a kind of hypostasis of God, through analogy with hypostases of the Christian trinity, also corresponding to a force of nature (Bīrūnī 1858, 45-46; 1888, 1: 94). In spite of these problematic overlaps, it is clear that Bīrūnī sees Indian religion as intelligible within monotheistic categories of creator God, mediating angels (including Brahman), a prophetic figure (Nārāyan), and the sages who also seem to have had true access to truth in the way that Socrates is approvingly said to have had (Bīrūnī 1958, 12; 1888, 1: 24-25). Whatever we might make of the complexities of Bìrūnī's attempt here to force square Indian pegs into round Muslim holes, we can assess his modelling

31. Daniel Gimaret, "Șifa," EI2.

32. In his notes on the translation Sachau glosses this as the Veda, though the Arabic just refers to a Book (kitāb). (Bīrūnī 1958; 1888, 13; 1888, 1: 28).

33. A. Rippin and A.J Wensinck, "Wahy," EI2.

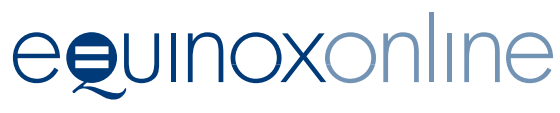


of Indian ideas as both precedented and unique. Unique, in that in the India, (in contrast to the Āthär) he largely ignores the rich old reservoir of Persian and Muslim legendary lore about Brahman as a philosopher king, and does not rely on the theologians' stereotype about the Barähima being prophecy-deniers. However, his description relies on earlier Muslim and Persian models of sages, prophets and angels.

Perhaps because of Bīrūnī's maverick replacement of traditional wisdom about India in preference to the direct use of Indian texts and informants, his India does not appear to have been greatly influential before the modern era. ${ }^{34}$ For an intervention in a tradition to be successful, its originality must, perhaps be filtered through models already well-established in that tradition. While Mas' ūdī successfully synthesized Indian religious history into a comprehensibly Muslim form, Bīrūnìs efforts to compare Indian religious terminology with Muslim terminology remained perhaps too abstract. However, he was not the last Muslim thinker to attempt to fit Indian religious ideas within a universalizing taxonomy of comparative religion. Shahrastānī is comparable to Bīrūnī insofar as he is not bound by the understanding of India based on origin myths. Shahrastānī's account of Indian religions is based substantially upon Muslim-era reportage, including the fact-finding mission sent to Sind by Yahyā b. Khālid al-Barmakī (Lawrence 1976, 21-29) ) $^{35}$ and shaped according to a taxonomical framework drawing upon the ideas of earlier theologians and heresiographers ${ }^{36}$ in addition to a few other sources, such as the account of Indian religions and the spread of Pythagoreanism to India by the neoplatonist philosopher Ammonius. ${ }^{37}$ Shahrastānī and Bīrūnī both use Indian religions as a way of critiquing the shortcomings of certain tendencies among Muslims. However, Shahrastānī's touchstone for assessing religious validity is almost exactly the opposite of Bīrūnī's rationalism. For Bīrūnī, for example, idolatry should be rejected because it is deemed unacceptable to reason. In contrast, Shahrastānī's taxonomy of true religion is based not on the touchstone of reason, but on the capacity to abandon one's own

34. Though Abū al-Ma'ālī has a superficial summary of Bīrūnì's contribution on India. (Lawrence 1976, 25).

35. Again, Shahrastānī drew upon reportage drawn from of the fact-finding mission sent to Sind by Yahyā b. Khālid al-Barmakī. Lawrence, Indian Religions, 21-29.

36. This reliance on earlier theological categories also results in a prominent place for the idea of the Barāhima as prophecy-deniers, and the refutation of their theses. (Lawrence 1976, 38-41, 75-100).

37. See passage quoted below.

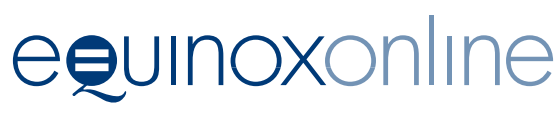


opinion in submission (islām) to the decrees of another, outside authority; including the authority of a prophet, (and, implicitly, perhaps an Imam), a revealed book, or, failing these, laws set down by earlier generations:

"Those who follow only their own judgements are [also] those who deny prophecies, such as the philosophers, Șābians and Brahmans; they do not accept ordained laws and statutes. [On the other hand], those who utilize the teachings of others also accept prophecies. And those who accept divine ordinances also subscribe to rational statutes and not vice versa." (Lawrence 1976, 65) ${ }^{39}$

On this basis, then, the following hierarchy of religious validity is produced:

- Muslims

- Non-Muslims who possess a revealed book, i.e. Jews and Christians

- Those who possess something like a revealed book, i.e. Magians and Manicheans

- Those who subscribe to laws and binding judgements without the benefit of a revealed book, i.e. the ancient Șābians

- Those who have neither a revealed book nor fixed laws, i.e., the ancient as well as the materialist philosophers, the star- and idol-worshippers and the Brahmans. (Lawrence 1976, 64)

This hierarchy then reproduces and theorizes the old distinctions between Muslims, People of the Book, and "polytheists" mushrikūna. In this scheme, the boundaries separating the Muslim community are preserved by the identity of the authority to whom one submits. Thus, in his chapter on the Indian sect of "idol-worshippers," Shahrastānī suggests that idolatry is the end result of misdirected worship. When one worships something other than the true God, concrete objects are employed to fill the vacuum (Lawrence 1976, 52). Unlike Bīrūnì's assessment of idolatry as something that all religious communities may fall prey to, for Shahrastānī it ultimately derives from the worship of the wrong object, the wrong God. This insight ultimately tends towards the exclusion of communities according to how far they are from the authoritative revelations of God's prophets. While this bespeaks an anti-cosmopolitan separation of Muslim experience from that of other communities, Shahrastānī's taxonomical approach can, like Bīrūnī's allow for comparisons to be made across religions, on the basis of what are understood to be universal principles. Thus Greek philosophy is,

38. Note the debate surrounding the question of whether Shahrastānī sympathized with Ismailism, summarized and discussed by Steigerwald (2006, 262-273).

39. Here and in what follows I use Lawrence's translations.

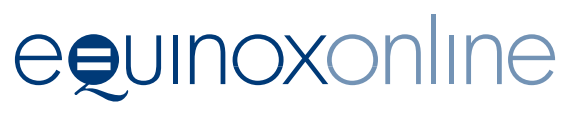


on the whole, favorably treated. This favorable apprehension of Greek philosophy is the product of several generations of engagement and absorption of Greek thought as part of the Muslim tradition (Gutas 1998), and this tolerance comes to be extended to Indian philosophy also, ${ }^{40}$ especially in a story about the Indian followers of Pythagoras. It is in this passage, drawn from Ammonius, that we see an account of the sage or philosopher-king as primogenitor of an Indian religious and political community:

\begin{abstract}
Pythagoras, the Greek sage, had a student named Qalānūs who, after he had learned wisdom from Pythagoras and studied under him, went to one of the cities of India and there promulgated the Pythagorean viewpoint. Now there was one Braḥmanān, a man of intellectual refinement, incisive judgements and unerring reason, who was also eager to know about the upper worlds. He learned wisdom from Qalānūs the Wise and appropriated the latter's knowledge and skill. After the death of Qalānūs, Brahmanān came to rule over all India. He spurred the people to purify their bodies and to purge their souls. (Lawrence 1976, 56)
\end{abstract}

The sage, Brahmanān, represents a clear parallel to the legendary king Brahman in other accounts and he plays a similar, quasi-prophetic role of founding a religio-political community on the basis of his wisdom. Here the comparison between Indian and Greek philosophers is made explicitly. Thus, while Sharastānī's heresiographical taxonomy tends towards the hierarchical exclusion of non-Muslim and non-prophetic religious communities, he too seems to accept a widespread appreciation of the role of philosophical sages as the founders of religious communities whose religious traditions are independently valid. While Sharastānìs taxonomy tends to exclude, his use of narrative can be seen to build bridges.

\title{
Conclusion: Cosmopolitanism, elitism and violence
}

To sum up, we have looked at two major fields for the discussion of cosmopolitanism: the narrative-historical and the theological-doctrinal. In each, one can discern a tension between cosmopolitan and anti-cosmopolitan tendencies. In the historical-narrative field, anti-cosmopolitan narratives imply the denial of common origins between communities ('umma, 'umam) while cosmopolitan narratives, on the other hand, assert the relatedness of human societies: either direct relation by blood, or relation through the common divine origins of the foundation-moment of the respective communities. In theological-doctrinal accounts of the structure of human societies, doctrinal factors account for the difference and similarity between

40. See, for example, his assessment of the ideas of the Bakrantiyya, and those who, in contrast to the Barāhima, attest to a pseudo-prophetic or angelic mechanism of mediation with the divine. (Lawrence 1976, 44-47, 73).

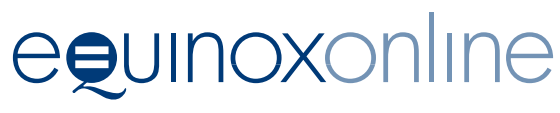


human groups. An anti-cosmopolitan account emphasizes the distinction between communities, based on defining touchstone-doctrines which assert impregnable boundaries between groups. Cosmopolitan accounts would tend to emphasize the porousness of these boundaries, due to the existence of doctrinal similarities across confessional divides.

From a modern perspective, it might seem strange to entrench a discussion of cosmopolitan thinking within the debate over how an 'umma, a religious or national community, was understood to have been founded by a prophet, king or sage. These questions, however, were at the heart of the understanding of the place of different peoples and different religious traditions in the world, and therefore the extent to which outsiders could be understood to be "citizens of the world" on a similar footing as Muslims residing at the heart of an imperial 'Abbasid or post-'Abbasid metropolis. Therefore any pre-modern formulation of cosmopolitan thinking within the Muslim tradition will inevitably deal with the issues discussed in this article. That being said, a number of factors have emerged which structure the kind of cosmopolitan thinking visible in the authors analyzed. One is the importance of discipline in defining the orientation of discourse. Having passed swiftly over the important legal (figh) division of communities between Muslim, protected monotheist (dhimmī, ahl al-kitāb), and infidel (mushrik), the major disciplinary division I have outlined is that between historiography and theological taxonomies of doctrine. In the historiographical vision exemplified by Ya'qūbī's History and Mas'ūdī's Murūj al-dhahab, the master principle that structures various narratives is that of the origination and fate of particular communities founded by prophets and kings, and facilitated by sages. This principle tends to equate the experiences of different nations, who receive the truth but then are liable to fall into fragmentation and error. While the Muslim community has a special place as the community of divine guidance, the historical processes that affect the Muslim community are seen as universal, and project a certain kinship between all communities. This kinship is most explicitly visible in Mas 'ùdì's Murūj, in which, I argue, the heresiographical paradigm of a foundational figure bringing insight into the truth followed by corruption and fragmentation is applied to the Indian religious community as well as to monotheistic religions. On the other hand, the theological taxonomies exemplified by Bīrūnī and Shahrastānī use what are understood to be universally-applicable Muslim standards to judge other religious traditions. Though this asserts a hierarchy of truth, in the case of Bīrūnì it also equates the pure religion of the monotheistic elites across

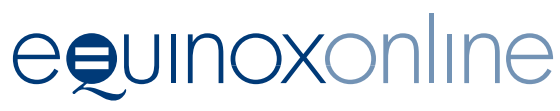


communitarian boundaries. All of these thinkers can be seen to participate in a broader phenomenon of the universalization of knowledge of the world, and the assimilation of knowledge to universalizing Muslim standards. Thus, as is well known, the Muslim universal histories of the 'Abbasid period famously synthesized all available knowledge about the historical communities of the known world into a single meta-narrative. In a less-well known phenomenon, the rise of comparative religion pioneered by thinkers like Ibn al-Nadīm, Nawbakhtī, Bīrūnī and Shahrastānī accomplished a similar act of assimilation and synthesis in the doctrinal realm, asserting a formal (if not essential) continuum between all doctrinal typologies extant among the different human religious communities. In order to produce such universalizing schemata, a certain intellectual elitism was necessary. The element of elitism is explicit in the work of Mas' $\bar{u} \bar{l}^{1}$ and Bīrūnī, who both see the intellectual and religions elites as carrying the burden of preserving knowledge. For Bīrūnī, the elites are responsible for preventing the masses from falling into idolatry-a task that has been failed in by Jewish and Christian leaders as well as Indians. In a similar spirit, Mas'ūdī, in his introduction to Murūj al-dhahab, describes his own purpose as a writer in terms of preserving knowledge of the elite for future generations, and providing the insights that only a learned, well-travelled, cosmopolitan intellectual can acquire:

And what prompted me to compose this, my book, on history and the narratives ( $a k h \bar{b} \bar{r}$ ) of the world and what passed along the byways of the ages regarding the narratives of the prophets and the kings and their vitae (siyar), and the nations ('umam) and their dwelling places, was that I loved to imitate the path which the learned men ('ulama') had headed for and which the sages (hukamä) had followed, so that there remained for the world a praiseworthy record (dhikr), and well-ordered and organized knowledge, ... Every region of the world (iqlim) has its wonders which the locals fail to understand. Someone who has remained in one corner of his homeland and believes in the stories that have been related to him about his region is not the equal of someone who has divided his life in crossing the regions (aqtār), and has apportioned his days to the battening blows of travels, and to extracting every fine thing from the mines of that region, and raising up every valuable thing from its hidden places. (Mas'ū $\mathrm{u} \overline{1}$ 1958, 1: 11)

This is a manifesto on the superiority of the cosmopolitan intellectual over local informants who, given their narrower experience of the world and their unfamiliarity with stories told in different regions, are seen as less able to judge clearly regarding the stories from their own traditions. In this passage, we see empirical studies by the cosmopolitan intellectual as a means of defending the common human tradition established

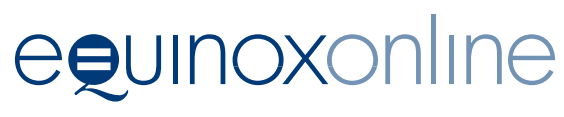


by kings, prophets and preserved by the national communities that they have founded. Mas'ūdī himself, then, aims to participate in the mission of the sages and learned men who recorded the histories for posterity. Here, then, not only is knowledge of other traditions not considered to be taboo or corrosive, but rather knowledge of other traditions increases one's apprehension of the truth. This is the cosmopolitanism of a self-consciously wise elite rather than all humans as "citizens of the world." Such an elitism was also a component of the original stoic formulations of cosmopolitanism (Pagden 2000, 5).

If we view the production of universal histories as a cosmopolitan project, it can help us understand better the relationship between the particular and the universal which they posit. On one hand, we must agree with Chase Robinson when he says,

There is no confusing al-Ya 'qūbī's or al-Mas 'ūdī's work with what would now be called a multi-cultural textbook of world history. The latter may have been a humanist of sorts, and this a good century before an Islamic humanism enjoyed its brief efflorescence. But he is a thoroughly monotheist one. ... The purpose of pre-Islamic history is to provide a sort of praeparatio evangelica for the events of the early seventh century and what followed: the prophecy of Muhammad and the caliphs, all ruling in his succession... It is universal history of a selective and very purposeful sort. (Robinson 2003, 138)

However, we can shift the emphasis a little. Given the diversity of national narratives incorporated, the project of the universal histories was not, and could not have been restricted to a single central aim. Even in subordinating these narratives to the sacred history of Muhammad's prophecy, the universal histories also had to come to terms with the plurality of human experience, and to accept the witness of non-Muslims regarding the experience of these other communities. Nonetheless, it would be a mistake to overemphasize the effects of this kind of cosmopolitan thinking. While we have seen hybridizing tendencies among the informants of our historians, the writers studied here were nonetheless engaged in a shared project of validating the precepts of Islam against other less-perfect traditions. Nonetheless, we can also detect powerful potential for bridge-building in the mechanisms employed, which emerge in a fuller form in later contexts. Thus, we see the syncretizing potential of the form of the universal history centered upon prophets, kings and sages explored more fully in, for example, the work of Mughal-era historians and thinkers who built upon a reservoir of texts and ideas produced in the pre-Mongol era. We might take as an example the Mughal court historian Tattawi

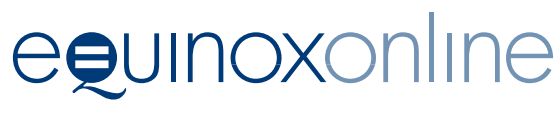


who relies on the familiar framework through which prophets, sages and philosophers are conflated as figures of authority, allowing him to defend the doctrine of reincarnation at the time of Akbar's syncretistic project to unite Hindu and Muslim courtiers behind his charismatic leadership (Tattawī [2003 or 2004]), 1: 378). ${ }^{41}$ Likewise, we see a reemergence of an elitist syncretism founded upon similar conceptualizations of the prophets and the sages in the project of the Mughal prince Dārā Shukōh, who produced a translation of the Upanishads, which he saw as comparable to the revelations in the Qur'ān, while also decrying the degraded capacity of the masses to understand religious precepts (Friedmann 1975, 217).

While the seeds of a kind of cosmopolitan thinking existed in the theological reading of the history of the world produced pre-Mongol thinkers, however, such universalizing discourse does not presuppose a tolerant encounter with others. It has been noted that the key documents that attest to the empirical investigation of Indian thought in the pre-Mongol period (by Yahyā b. Khālid al-Barmakī's emissary and Bīrūnī) come in the wake of violence. Mas'üdì's travels to India also relied on the expansion of the Muslim footprint that the earlier conquests had created, including the use of the Muslim states in India and their allies as a foothold for his researches (Ahmad 1954, 509-524). However, neither are violence and intolerance necessary bedfellows. The logic of imperial rule can produce a selectively tolerant, even syncretizing intellectual environment as part of the objective of conquest. The Muslim "orientalist" scholarship on Indian religion in the ninth to eleventh centuries CE has certain parallels with the otherwise very different era of European orientalist scholarship, which also asserted certain cosmopolitan universals at the time of the rise of self-consciously rational and secular knowledge (Asad 2003). In both cases comparative religion appeared in the context of syncretizing projects to adapt and assimilate knowledge from other cultures, which coexisted alongside universalizing attempts to conquer the world through studying it, with the effect of reducing all knowledge within a supposedly objective taxonomy in which categories of thought masquerading as universal (but in reality reflecting a very particular set of historical genealogies) became the touchstone for judging competing systems of thought and practice (Asad 1993). This should act as a cautionary tale to scholars who seek to identify European orientalism as historically unparalleled in its

41. Thanks to my friend Said Reza Huseini for enlightening me in discussions of the subject of Akbar's project, and the Tārikh-i alfi, in particular. See also his study of the work (Huseini 2017).

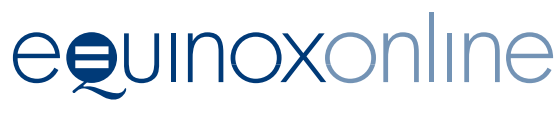


violent appropriation of the other. The intolerance of particularism is one of the inevitable pitfalls of a universalizing cosmopolitan thinking. For the other to become intelligible, it must be translated and domesticated into local categories, and to be accepted, it must be seen to accept such 'rational,' principles as monotheism or secularism. When such a translation and domestication occurs, the power dynamics between the scholar and the object of his study are inevitably incorporated into the categories that emerge. However, power is not the only framework for apprehending such scholarship. We might fruitfully quote Srinivas Aravamudan's comments on pre-19th century Enlightenment orientalism in this context:
European knowledge regarding the East [was] influenced by the utopian aspi- rations of Enlightenment more than materialist and political interest. Enlight- enment interrogation was not innocent - no knowledge ever is-but it was a complex questioning, with multiple objectives and orientations, "a state of intellectual tension rather than a sequence of similar propositions." Not just bent on the domination of the other but also aimed at mutual understanding across cultural differences, for Enlightenment the self was under critique as much as any "other." (Aravamudan 2012,3)

While the texts that we have examined do not amount to a thorough-going theory of cosmopolitanism, they do present certain broad tendencies towards cosmopolitan thinking in the elites of 'Abbasid and post'Abbasid world, in which the expansion of the horizons of the known world through conquest, travel and trade was accompanied by an assimilation of the ideas of the world to the Muslim canons of knowledge. This knowledge was not innocent, but involved an orientation both towards violence and towards mutual understanding.

\section{Acknowledgments}

This article was completed with the support of the Leiden research project "Embedding Conquest: Naturalising Muslim Rule (600-1000)" funded by the European Research Council (ERC) under the European Union's Horizon 2020 research and innovation programme, grant agreement 683194.

\section{References}

Abuladze, Ilia V. 1966. "Introduction." In The Balavariani (Barlaam and Josaphat): A Tale from the Christian East Translated from the Old Georgian. Translated by David Lang, 19-41. London: George Allen and Unwin.

Ahmad, S. Maqbul. 1954. "Al-Mas'udi's Contributions to Medieval Arab Geography: Some Sources of his Knowledge." Islamic Culture 28: 510-512.

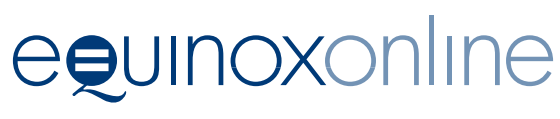


. 1954. "Travels of Abu 'l Hasan 'Alī b. al-Husayn al-Mas ūdē." Islamic Culture 28(1): 509-524.

. 1960. "Al-Mas'ūdī on the Kings of India." in Al-Mas' ūdì: Millenary Commemoration Volume, edited by S. Maqbul Ahmad and A. Rahman, 97-112. Aligarh: Indian Society for the History of Science.

Ahmed, Shahab. 2016. What is Islam?: The Importance of Being Islamic. Princeton, NJ: Princeton University Press. https://doi.org/10.1515/9781400873586

Almutawa, Shatha. 2013. "Imaginative Cultures and Historic Transformations: Narrative in Rasā’il Ikhwān al-Ṣafā', Unpublished Ph.D. thesis, University of Chicago.

Aravamudan, Srinivas. 2012. Enlightenment Orientalism: Resisting the Rise of the Novel. Chicago, IL: Chicago University Press. https://doi.org/10.7208/chicago/9780226024509.001.0001

Asad, Talal. 1993. Genealogies of Religion: Discipline and Reasons of Power in Christianity and Islam. Baltimore, MD: Johns Hopkins University Press.

2003. Formations of the Secular: Christianity, Islam, Modernity. Stanford, CA : Stanford University Press.

Bentley, Michael. 1999. Modern Historiography: An Introduction. London: Routledge.

Al-Bīrūnī, Abū Rayḥ̄an Muḥammad b. Aḥmad. 1888. Alberuni’s India. Translated by C. Edward Sachau. London: Trübner.

1879. The Chronology of Ancient Nations, translated by C. Edward Sachau. London: W.H Allen \& Co.

1958. Tahquīq mà li-al-hind min maqūla maqbūla fi-al-'aql aw mardūila. Hyderabad: Dairatu'l-ma'arifi'l-osmania.

Bosworth, C. E. 1991. "Farrukhī's Elegy on Mahmūd of Ghazna." Iran 29: 43-49. https://doi.org/10.2307/4299847

Bowen Savant, Sarah. 2013. The New Muslims of Post-Conquest Iran: Tradition, Memory, and Conversion. Cambridge: Cambridge University Press. https://doi. org/10.1017/CBO9781139013437

Brett, Michael. 1979. "The Arab Conquest and the Rise of Islam in North Africa," The Cambridge History of Africa 2, edited by J. D. Fage, 502-512. Cambridge: Cambridge University Press.

Buzurg ibn Shahriyār. 1981. The Book of the Wonders of India: Mainland, Sea and Islands. Edited and translated by G.S.P. Freeman-Grenville. London: EastWest Publishers.

Crone, Patricia. 2014. Medieval Islamic Political Thought. Edinburgh: Edinburgh University.

\section{eevunoxonlıne}


Dabashi, Hamid. 2012. The World of Persian Literary Humanism. Cambridge, MA: Harvard University Press. https://doi.org/10.4159/harvard.9780674067592

De Blois, François. 1990. Bürzōy's Voyage to India and the Origin of the Book of Kalilah wa Dimnah. London: Royal Asiatic Society.

Di Branco, Marco. 2010. "A Rose in the Desert? Late Antique and Early Byzantine Chronicles and the Formation of Islamic Universal Historiography." In Historiae Mundi: Studies in Universal History, edited by Peter Liddel and Andrew Fear, 189-206. London: Duckworth.

Donner, Fred. 2010. Muhammad and the Believers: at the Origins of Islam. Cambridge, MA: Harvard University Press.

Durkheim, Émile. 1995. The Elementary Forms of Religious Life. Translated by Karen Fields. New York: Free Press.

Gibb, H. A. R. 1962. Studies on the Civilization of Islam. Boston, MA: Beacon Press.

Gimaret, Daniel. 1971. Le Livre de Bilawhar et Būdāsf selon la version Arabe Ismaélienne. Geneva, Paris: Librarie Droz.

Eaton, Richard. 2000. “Temple Desecration and Indo-Muslim States," Journal of Islamic Studies 11(3): 283-319. https://doi.org/10.1093/jis/11.3.283

Eaton, Richard and Phillip Wagoner. 2014. Power, Memory, Architecture: Contested Sites on India's Deccan Plateau, 1300-1600. Oxford: Oxford University Press. https://doi.org/10.1093/acprof:oso/9780198092216.001.0001

van Ess, Josef. 1991. Theologie und Gesellschaft im 2. und 3. Jahrhundert Hidschra. Eine Geschichte des religiösen Denkens im frühen Islam. Berlin: De Gruyter. https://doi.org/10.1515/9783110868494

- 2011. Der Eine und das Andere Beobachtungen an islamischen häresiographischen Texten. Berlin: De Gruyter. https://doi.org/10.1515/9783110215786

Fārābī, Abū Nașr Muhammad ibn Muhammad. 2005. "The Book of Letters.” In Medieval Islamic Philosophical Writings, edited by Muhammad Ali Khalidi, 1-26. Cambridge: Cambridge University Press.

Friedmann, Yohanan. 1975. "Medieval Muslim Views of Indian Religions." Journal of the American Oriental Society 95(2): 214-221. https://doi. org/10.2307/600318

1986. "Islamic Thought in the Indian Context." In Islam et Societe en Asie du Sud, edited by X. Gaborieau, 79-91, Paris: EHESS.

2003. Tolerance and Coercion in Islam: Interfaith Relations in the Muslim Tradition. Cambridge: Cambridge University Press. https://doi.org/10.1017/ CB09780511497568

Gutas, Dimitri. 1998. Greek thought, Arabic Culture the Graeco-Arabic Translation Movement in Baghdad and early 'Abbasid Society (2nd-4th/8th-10th centuries). London: Routledge.

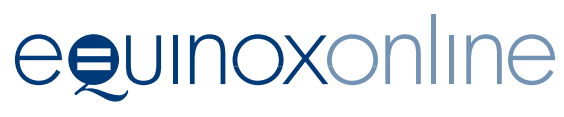


Hodgson, Marshall. 1974. The Venture of Islam. Chicago, IL: Chicago University Press.

Hughes, Aaron. 2017. "Religion without Religion: Integrating Islamic Origins into Religious Studies." Journal of the American Academy of Religion 85(4): 867888. https://doi.org/10.1093/jaarel/lfx010

Huseini, Reza. 2017. “The First Islamic Millennium and the Making of the Tarikh-i Alfi in the Sixteenth Century Mughal India." Unpublished MA thesis, Leiden University.

Ibn al-Nadīm, Abū al-Faraj Muhammad. 1971. Al-Fihrist. Edited by Riḍā Tajaddud. Tehran: [publisher not identified].

Ibn Bābūya, Abū Ja far Muḥammad b. 'Alī. 1975 (1395/1384). Kamāl al-dīn wa tamām al-ni'ma. Edited by 'Alī Akbar al-Ghaffārī. Tehran: Dār al-Kutub al-Islāmiyya.

Jeffrey, Arthur. 1951. "Al-Biruni's Contribution to Comparative Religion." In AlBiruni Commemoration Volume, 125-161. Calcutta: Iran Society.

Khalidi, Tarif. 1975. Islamic Historiography: The Histories of Mas' ū ${ }^{\prime} \bar{\imath}$. Albany: State University of New York Press.

Khalidi, Tarif. 1994. Arabic Historical Thought in the Classical Period. Cambridge: Cambridge University Press. https://doi.org/10.1017/CBO9780511583650

Al-Khașībī, Al-Ḥusayn ibn Ḥamdān. 2007. Al-Hidāya al-kubrā. Diyār 'Aql [Lebanon]: Dār li-ajl al-márifa.

Lapidus, Ira. 2002. Islamic Societies to the Nineteenth Century: A Global History. Second edition. Cambridge: Cambridge University Press.

Lawrence, Bruce. 1976. Shahrastani on the Indian Religions. Paris: Mouton. https:// doi.org/10.1515/9783110800999

Lueck, Bryan. 2014. "Appendix: On Cosmopolitanisms." In Iranian Identity and Cosmopolitanism: Spheres of Belonging, edited by Lucian Stone, 159-176. London: Bloomsbury.

Mackintosh-Smith, Tim, ed. and trans. 2014. Two Arabic Travel Books. New York: New York University Press.

Mas'ūdī, Abū al-Hasan 'Alī b. Husayn. 1938. al-Tanbīh wa al-ishrāf, edited by 'Abd Allāh Ismāî̀l al-Șāwī. Cairo: Maktabat al-Sharq al-Islāmiyya.

. 2005. Murūj al-dhahab wa ma'ādin al-jawhar. Edited by Kamāl Hasan Mar'̄̄o. Beirut: al-Maktaba al-'Așriyya.

Melvin-Koushki, Matthew. 2016. "Astrology, Lettrism, Geomancy: The Occult-Scientific Methods of Post-Mongol Islamicate Imperialism." The Medieval History Journal 19(1): 142-150. https://doi.org/10.1177/0971945815626316

\section{eevunoxonline}


Mottahedeh, Roy. 1976. "The Shu'ûbîyah Controversy and the Social History of Early Islamic Iran,” International Journal of Middle East Studies 7(2): 163. https://doi.org/10.1017/S0020743800023163

Al-Musawi, Muhsin. 2015. The Medieval Islamic Republic of Letters. Notre Dame, IN: University of Notre Dame Press.

Orwin, Alexander. 2017. Redefining the Muslim Community: Ethnicity, Religion, and Politics in the Thought of Alfarabi. Philadelphia: University of Pennslyvania Press. https://doi.org/10.9783/9780812293906

Pagden, Anthony. 2000. "Stoicism, Cosmopolitanism, and the Legacy of European Imperialism." Constellations 7(1): 3-22. https://doi.org/10.1111/14678675.00167

Papaconstantinou, Arietta. 2008. "Between Umma and Dhimma: The Christians of the Middle East under the Umayyads." Annales Islamologiques 42: 127-156.

Pingree, David. 1963. "Astronomy and Astrology in India and Iran.” Isis 54(2): 229246. https://doi.org/10.1086/349703

1968. The Thousands of Abū Ma'shar. London: The Warburg Institute/Brill.

Pourshariati, Parvaneh. 1995. "Iranian tradition in Tus and the Arab presence in Khurasan." Unpublished PhD thesis, Columbia University.

2004. "Khurasan and the Crisis of Legitimacy." In Views from the Edge: Essays in Honor of Richard W. Bulliet, edited by Neguin Yavari, Lawrence G. Potter and Jean-Marc Ran Oppenheim, 208-229. New York: Columbia University Press.

Robinson, Chase. 2003. Islamic Historiography. Cambridge: Cambridge University Press.

Robinson, Majied. 2013. "Prosopographical Approaches to the Nasab Tradition: a Study of Marriage and Concubinage in the Tribe of Muhammad, 500-750 CE." Unpublished PhD thesis, Edinburgh University.

Rosenthal, Franz. 1970. Knowledge Triumphant; the Concept of Knowledge in Medieval Islam. Leiden: Brill.

Sijpesteijn, Petra. 2013. Shaping a Muslim State: The World of a Mid-Eighth-Century Egyptian Official. Oxford: Oxford University Press. https://doi. org/10.1093/acprof:oso/9780199673902.001.0001

Steigerwald, Diana. 2006. "Al-Shahrastānī's Contribution to Medieval Islamic Thought." In Reason and Inspiration in Islam: Theology, Philosophy and Mysticism in Islamic Thought, edited by Todd Lawson, 262-273. London: I.B. Tauris.

Stroumsa, Sarah. 1985. "The Barāhima in Early Kalām." Jerusalem Studies in Arabic and Islam, 6: 229-241.

\section{eevunoxonlıne}


Tabarī, Abū Ja far Muhammad Ibn Jarīr. 1986. The History of al-Ṭabarī, vol. 2 History of the Prophets and Patriarchs. Translated by William Brinner. Albany: State University of New York Press.

Tattawī, Ahmad and Āṣif Khān Qazwīnī. 1382 [2003/4]. Tārīkh-i alfī. Edited by Ghulām Rị̣ā Tabātabāīi Majd. Tehran: Intishārāt-i 'Ilmī va Farhangī.

Tavakoli-Taraghi, Mohamad. 1996. “Contested Memories: Narrative Structures and Allegorical Meanings of Iran's Pre-Islamic History." Iranian Studies 29:(1-2): 149-175. https://doi.org/10.1080/00210869608701847

Tha'ālibī. 1979. Histoire des Rois des Perses. Edited and translated by Hermann Zotenberg. Amsterdam: Oriental Press.

Van Bladel, Kevin. 2011. "The Bactrian Background of the Barmakids." In Islam and Tibet: Interactions Along the Musk Routes, edited by Anna Aksoy, Charles Burnett and Ronit Yoeli-Tlalim. Farnham: Ashgate.

Waardenburg, Jacques, ed. 1999. Muslim Perceptions of Other Religions. Oxford: Oxford University Press.

Webb, Peter. 2016. Imagining the Arabs: Arab Identity and the Rise of Islam. Edinburgh: Edinburgh University Press. https://doi.org/10.3366/edinburgh/9781474408264.001.0001

Wink, André. 2002. Al-Hind, the Making of the Indo-Islamic World. Leiden: Brill.

Ya qūbī, Aḥmad b. Abī Ya'qūb. [c. 1980]. Tārīkh. Beirut: Dār Șādir.

\section{eevunoxonline}

